\title{
Open
}

\section{A dynamic capabilities-based entrepreneurial theory of the multinational enterprise}

\section{David J Teece}

Institute for Business Innovation, Haas School of Business, UC Berkeley, USA

\section{Correspondence:}

DJ Teece, Berkeley Research Group, 2200 Powell Street, Suite 1200, Emeryville, CA 94608, USA.

Tel: +1 5102853300 ;

Fax: +1 5102853271 ;

email: teece@haas.berkeley.edu

\begin{abstract}
This paper develops a dynamic capabilities-based theory of the multinational enterprise (MNE). It first reviews scholarship on the MNE, with a focus on what has come to be known as "internalization" theory. One prong of this theory develops contractual/transaction cost-informed governance perspectives; and another develops technology transfer and capabilities perspectives. In this paper, it is suggested that the latter has been somewhat neglected. However, if fully integrated as part of a more complete approach, it can buttress transaction cost/governance issues and expand the range of phenomena that can be explained. In this more integrated framework, dynamic capabilities coupled with good strategy are seen as necessary to sustain superior enterprise performance, especially in fast-moving global environments. Entrepreneurial management and transformational leadership are incorporated into a capabilities theory of the MNE. The framework is then used to explain how strategy and dynamic capabilities together determine firm-level sustained competitive advantage in global environments. It is suggested that this framework complements contract-based perspectives on the MNE and can help integrate international management and international business perspectives.
\end{abstract}

Journal of International Business Studies (2014) 45, 8-37. doi: I0.1 057/jibs.2013.54

Keywords: transaction cost theory; transaction cost economics, or transaction cost analysis; internationalization theories and foreign market entry; competitive advantage; dynamic capabilities and capability development; entrepreneurship business strategy; intellectual capital

The online version of this article is available Open Access

\section{INTRODUCTION}

A multinational enterprise (MNE) is a business firm that sets strategy and manages operations for the development and utilization of income-generating assets in more than one country in the pursuit of profits over time. A robust theory of the business enterprise ought to be able to provide insight into global scope, network characteristics, and the basis of sustained competitive advantage (SCA), if any. Accordingly, the study of international business should not be divorced from the study of international management, and the theory of the MNE should not be a distant cousin to the theory of the business enterprise more generally. However, incomplete global integration and the existence of heterogeneous national economies and geographies leave special issues and considerations that a theory of the MNE must embrace, but hasn't yet done so.
Received: 15 December 2011
Revised: 27 August 2013

Accepted: 31 August 2013 
The theory of the firm has long contended with issues such as why firms exist and what determines their boundaries. More specifically, a robust theory of the firm should also be able to explain:

(1) why some firms grow and go global while some firms stay domestic;

(2) the product, as well as geographical identity and scope, of the firm's activities ${ }^{1}$;

(3) market-entry timing and mode; and

(4) explain the drivers of foreign direct investment (FDI) and the role of subsidiaries.

Most critically, an acceptable theory of the MNE should be able to provide insight into how the enterprise builds and protects SCA. ${ }^{2}$

This paper endeavors to fill voids and inadequacies in the theory of the MNE and competitive advantage by drawing on scholarship on organizational capabilities, ${ }^{3}$ business strategy, and entrepreneurship. One goal is to bring greater cohesion to the field of international business by securing convergence between "internalization scholars" and what I will call "international management scholars", such as Bartlett, Ghoshal, and Doz, who have come to eschew internalization theories in favor of other approaches. Another goal is to bring greater integration with the field of strategic management, which also claims to have something to say about the SCA of global firms. A third goal is to respond to the challenge of several scholars to bring the international business literature into better contact with entrepreneurship theory. Mark Casson (1986b: 54) some time ago called for a "dynamic theory of countries' advantages using the economic theory of the entrepreneur". ${ }^{4}$ Jones and Wadhwani (2007: 2) likewise recognized the opportunity and the need to employ "an entrepreneurial perspective to deepen our understanding of aspects of the history of global capitalism".

A final goal is to integrate economic, organizational, and entrepreneurial theories of the firm by demonstrating how both governance and entrepreneurship/capabilities perspectives are needed to shed light on the nature of the MNE, and the foundations of SCA. ${ }^{5}$ I agree with my UC Berkeley colleague Oliver Williamson that capabilities and governance perspectives are "both rival and complementary ... more the latter than the former" (Williamson, 1999: 1106). I also submit that the capabilities view encompasses governance/contractual views and can provide the framework within which governance/transaction cost minimization decisions take place. ${ }^{6}$
These four goals constitute an ambitious, multidisciplinary agenda. That agenda transcends the deep theoretical issues addressed by Frank Knight (1921) and by Nobel Laureate Coase (1937). ${ }^{7}$

The structure of the paper is as follows. It begins with a review of a number of early approaches to the theory of the MNE, and then identifies various shortcomings, with attendant hints as to how one might amend these deficiencies. The direction of travel is toward a capabilities theory, which is embellished as the paper evolves. The framework is then applied to classic MNE questions, and exploratory insights are reviewed. The paper builds upon earlier efforts to bring capabilities into the theory of the MNE (Augier \& Teece, 2007, 2008; Pitelis \& Teece, 2010; Teece, 2006a). Because of the richness in existing theories in the field of international business and prior efforts to bridge some of the divides (e.g., Rugman \& Verbeke, 1992, 2003), there is plenty of good scholarship to draw upon and to incorporate into the capabilities/entrepreneurship framework, thereby hopefully creating a more robust and integrative theory of the MNE, while simultaneously blurring the lines between the international business and international management literatures.

\section{CONTEMPORARY THEORIES OF THE MNE}

The internalization perspective has dominated much of the literature on the MNE over the past 30 years (Dunning \& Lundan, 2008). This perspective attempts to explain the reasons for international production and the phenomenon of the MNE by appealing to "market failure" considerations. Such "failures" help explain why firms internalize transactions across national borders. However, the perspective does not address the reasons for differential firm performance. $^{8}$

The internalization perspective is arguably more robust than the earlier Hymer-Kindleberger paradigm. The former is substantially an efficiency-based explanation of FDI and the MNE; the latter a market power explanation. While Hymer (1968) did note in one article a specifically Coasian justification for internalization, he was deeply wedded to standard theories of the firm, and to the Mason-Bain structure-conduct-performance paradigm of industrial organization (Dunning \& Pitelis, 2008). Hymer's analysis became impaired when he quickly moved from determining that the MNE had special advantages to asserting that the exploitation of its monopoly power and monopolistic advantages was the main reason for its existence and evolution, and was 
therefore something to be regulated or otherwise limited by government controls (Teece, 1981a). ${ }^{9}$

The internalization school advanced understanding of the MNE beyond where Hymer left it, not least by emphasizing market failures due to contracting problems. This led to an efficiency-based explanation of the MNE. There are two prongs (rationales) to internalization:

(1) transaction costs/hold-up issues that are avoided by internalization; and

(2) resource transfer cost savings and learning issues, which are facilitated when technology transfers occur inside the MNE.

The first prong was advanced by Buckley and Casson (1976), Dunning (1981), Rugman (1981), Teece $(1975,1976,1981 a)$, Williamson (1981), and others. This particular internalization "school" sees contractual issues and associated market failures as the crucial reason for internalization. This class of papers can be thought of as representing the transaction-cost-based, comparative-governancebased, or exchange-based theory of internalization. ${ }^{10}$ Early contributions in this vein (e.g., Casson, 1979) explicitly viewed it as a two-way street, noting that internalized transactions could, when circumstances warranted, be externalized (outsourced), but that awareness has generally given way to a narrower focus on what firms choose to integrate.

Buckley and Casson's (1976) work was the most thorough early attempt in this genre to extend Coase's (1937) paper into the global context. They argued that MNEs minimized transaction costs resulting from the public goods aspects of some intermediate, mostly intangible, assets via global coordination and the managerial control of these assets. This prong of the internalization school examined the relative advantages associated with different entry modes (e.g., exports, licensing, and FDI). In this same vein, Hennart (1982) explored conditions under which international interdependencies could be dealt with in a transaction-costs-efficient manner through employment contracts, rather than arm's length market transactions. Rugman (1981) also highlighted the role of MNEs in overcoming market imperfections in international markets. ${ }^{11}$ This version of the internalization paradigm has become so pervasive that Mark Casson could quite correctly claim that by the mid1980s "the modern theory of the MNE is essentially a general theory of contractual relations in international business" (Casson, 1986a: 6).

The second and relatively neglected prong to internalization does not see its essence as resulting from transaction costs saved because hold-up risks are abated. Rather, it emphasizes the common (organizational) culture of an integrated enterprise and the ease of coordination inside the firm, as compared with coordination through the market. Besides easing potential contractual problems, integration opens pathways to learning, and to sharing know-how and expertise through cross-border technology and know-how transfer within the MNE. In this view, the MNE also provides for easy interchange of personnel across borders, and for better appropriability and trade secrecy. It thus mitigates intellectual property concerns, too, since technology transfer is to wholly owned business units and not to third parties, purportedly yielding greater control.

In this second prong of the theory, facilitating opportunity identification, personnel exchanges, learning, integration, and assisting in technology transfer are likely to be very important, and cannot all be squeezed under the rubric of economizing on transaction costs. The essence of the MNE in this prong of the literature is less about saving on transaction costs and more about being entrepreneurial and effective in the development, transfer, and orchestration of differentiated organizational and technological capabilities (Teece, 1981a). Cantwell (1989) developed a variant of this prong and called it the "industrial dynamics" and technological accumulation perspective, as it moved the focus away from industrial structure toward industrial evolution in which FDI led to the generation of "fresh technological advantages" abroad and at home (2).

This second prong has evolved into a knowledgebased approach to the MNE. Somewhat in the spirit of Teece (1976, 1977a, 1981a), Kogut and Zander (1992) saw the MNE as an instrument for generating and harboring tacit and explicit knowledge, and for transferring technology and industrial know-how across borders. In these formulations, the expansion of enterprise boundaries required and facilitated the transfer of knowledge. Internal knowledge transactions are preferred, not primarily for transaction cost reasons, but because of the lower resource costs of transmitting knowledge internally vs across a market (Tallman, 2003; Teece, 1976, 1977a). In Kogut and Zander's model, opportunism is rejected as an ongoing factor because firms exist to provide a social community supporting voluntaristic actions.

Both prongs of internalization provide important and relevant insights into the MNE. Cantwell (1989) was early to recognize the need to combine contractual frameworks with a theory of capability 
development. Notwithstanding his early contributions, international business scholarship has left capabilities considerations underdeveloped, to its considerable detriment (e.g., Birkinshaw \& Hood, 1998; Cantwell, 2009; Langlois, 2007). Because of the shortcomings of the first prong set out in the next section, the time is now ripe for the second prong (i. e., capabilities) to be strengthened, augmented with entrepreneurial considerations, and linked to a transaction-cost-based comparative governance perspective. ${ }^{12}$ Once this is accomplished, the second prong ought to be sufficiently robust to serve as the structure within which the transaction cost perspective can be nested.

\section{SOME SHORTCOMINGS OF NAKED TRANSACTION-COST-BASED THEORIES OF THE MNE}

In this section, I first highlight some shortcomings of the quasi-neoclassical transaction-cost-comparative governance perspective, and then provide hints as to how these can be remedied. ${ }^{13}$ Subsequent sections aim to provide a combined entrepreneurial/ capabilities conceptual perspective within which transaction costs can be contained.

\section{Capabilities and Learning Unexplored}

Early contributions to internalization, such as Hymer (1976), Buckley and Casson (1976), and, to some extent, Williamson (1981), drew to varying degrees on neoclassical marginal analysis and ignored or underplayed the importance of dynamics and, in particular, learning and capability augmentation. Even when the framework was broadened to include additional phenomena, capabilities and learning were neglected. For instance, in explaining the boundaries of the MNE, John Dunning (1995) suggested that ownership and location matter along with internalization factors (his OLI model). Buckley and Casson (1998) seemed to accept these elements, too. In subsequent work, moreover, Buckley and Casson have endeavored to address dynamics, innovation, flexibility, real options, international entrepreneurship, joint ventures and cultural issues. They have not, however, embraced issues of capabilities in a robust manner. Buckley (forthcoming) summarizes this impressive work and explains why behavioral and sociological views are hard to integrate with internalization, as they do not follow the rational choice axioms. While the challenge is considerable, the goal (theoretical integration) is attainable. Earlier work by Teece (1982) shows that transaction-cost-type and capabilities-type theories can coexist. Furthermore, one possible interpretation of the ownership factor in Dunning is that it is a proxy for capabilities (albeit a static one, particularly in early iterations of the OLI model). ${ }^{14} \mathrm{It}$ is clear that initial steps toward a capabilities approach have already been taken.

However, even if Dunning's ownership factor is interpreted as embracing firm-specific factors and national institutions (systems of innovation and production), and even if the ownership factor is accepted as a proxy for firm-level capabilities, there is still a dearth of theoretical structure and content around their nature, origins, orchestration, replicability/ transferability, and imitability. This is because neither transaction-cost-based internalization theory nor OLI explains very well the sources of firm-level asset ownership and capability advantages vis-à-vis competitors. While capabilities are obviously built in large part through learning, the $O$ factor in Dunning has little to say about that (Pitelis, 2007). ${ }^{15}$ It is important to recognize that learning is a key mechanism by which firm-specific assets develop. ${ }^{16}$

In more recent writing, Dunning and Lundan use the path-dependent resources and capabilities of a firm and its institutional infrastructure to explain dynamic growth, and highlight the need to link the microstructure of capabilities to the evolution of the (institutional) macrostructure (Cantwell, Dunning, \& Lundan, 2010; Dunning \& Lundan, 2008). Although this recent scholarship has been helpful in enhancing our understanding of the dynamics of the internalization process of firms, large gaps nevertheless exist. The theory of technological accumulation discussed in Cantwell (1989) remains an important mechanism by which firms build technological capabilities. However, given the ever-greater global dispersion of technology, reliance on in-house R\&D as the sole basis of competitive advantage is no longer tenable. Technologies from both within and beyond the enterprise must be orchestrated effectively to achieve timely delivery of differentiated products and services that customers value (Augier \&Teece, 2007; Pitelis, 2004).

\section{Cross-Border Market Creation and Co-Creation Ignored}

Market creation and co-creation are both entrepreneurial and dynamic concepts that have always been seminal functions of the MNE. However, market creation and co-creation have been largely ignored in the first (transaction cost) prong of the internalization literature. These activities are very different from market-entry mode selection decisions, upon 
which MNE theory has in recent decades put so much emphasis (e.g., Brouthers, 2013; Hennart, 2009; Zahra, Ireland, \& Hitt, 2000).

The transaction cost approach to internalization theory has focused on entry mode - such as procurement/supply contracts, joint ventures, and wholly owned subsidiaries. To explain entry mode, transaction cost theory implicitly assumes preexisting markets, which "fail" under certain conditions (e.g., where asset specificity or complex know-how transfers are involved), necessitating the emergence of the MNE and FDI to address these failures by internalizing (under a management structure) transactions that would otherwise likely evolve in an unfavorable way for one of the parties. However, it has long been recognized that the market failure assumption is merely an analytic convenience. Markets only fail relative to a hypothetical perfect market, which rarely exists. Infatuation with market failure and the functions (or lack thereof) of markets has deflected attention away from more important issues around the very existence of markets. Market creation and co-creation functions are not merely a response to a market that has somehow failed to perform (relative to an idealistic standard). Rather, it is often the case that the market has quite simply failed to emerge and/or needs to be created or co-created (Pitelis \& Teece, 2010) by entrepreneurially managed business enterprises. ${ }^{17}$

Put differently, even if markets do exist, they may be very thin or otherwise imperfect. This is particularly true for more specialized, idiosyncratic, and uncertain demand-and-supply requirements and opportunities. ${ }^{18}$ Hence, rather than solving transactional difficulties by simply internalizing all activity, entrepreneurial MNE managers must often consider what is tantamount to creating markets for ideas or for products, and bolstering the capabilities of suppliers in order to have markets they can sell into or from which they can source raw materials and components. A market creation and co-creation view of the MNE is obviously rather different from contractual approaches. ${ }^{19}$

It follows from the above that the rationale for the MNE is not just to achieve efficiencies (relative to some external benchmark) from internal transfers of technology and intermediate products, but also to create and manage co-specialization and, if need be, to create new markets and expand old ones. Indeed, it is recognized elsewhere in this paper that a prime reason why MNEs exist is that their cross-border presence, entrepreneurial capacities, and organizational capabilities are integral to the market creation and co- creation process, both upstream and downstream, and also laterally.

Some consideration of market creation is already present in Casson's important work on entrepreneurship (Casson, 1982, 1997, 2005). However, market-making in his theory is rather neoclassical, overly focused on individual action, and not linked very well to the MNE. In particular, Casson's approach does not seem to recognize the importance of the capabilities of the enterprise and its management in shaping markets, influencing trends, shaping demand, and assembling the complements needed for new markets to be viable.

The reality that needs to be reflected in the theory is that entrepreneurial MNEs can help build the new ecosystems within which global firms operate. MNEs facilitate investment in complements and other infrastructure needed for new products to be launched successfully. By investing in complements, MNEs can enhance the vitality of particular business ecosystems. Ecosystems are thus partly endogenous, as they are often co-created by (global) companies. ${ }^{20}$ This is in contrast to Porter $(1980,1985)$ and the basic industrial economics model, which has the industry as the domain of analysis, and market structure determined exogenously. In this paper, the concept of ecosystems (not the industry) is advanced as the appropriate domain for competitive analysis.

\section{Entrepreneurship Suppressed, Equilibrium Assumed, Management Muted, Leadership Ignored}

The Coasian view of the firm has resources allocated and decisions made by a manager who internalizes transactions until an indifference point is reached where the marginal cost of internalization is equal to the marginal cost of relying on the market. These perspectives employ neoclassical tools (both marginal analysis and equilibrium concepts) to explain management behavior and the nature of the enterprise. Moreover, factors of production and technology are given, and prices are (implicitly) known. The economic problem (or business model choice) becomes one of whether to engage in market exchange or in (vertical) integration. In a cross-border context, the latter implies FDI. ${ }^{21}$ In the Coasian firm, there is at best a modest role for the manager, no room for the entrepreneur, and no need for the leader.

Williamson $(1981,1985)$ extended Coase by deepening the contractual underpinnings of the transaction cost framework. In so doing, he created a predictive model of firm boundaries by featuring the role of asset specificity. In Williamson's contractual 
schema, bounded rationality coupled with uncertainty leads to an inordinate number of potential contingencies, which in turn render complete contingent-claims contracting impossible. Contracts are therefore necessarily incomplete. This in turn leads to recontracting hazards. These are mitigated, if not eliminated, by internalization. Location issues are not addressed, except indirectly (i.e., inasmuch as they impact transaction cost). ${ }^{22}$

In short, in endeavoring to build a theory of the firm, neither Coase nor Williamson focused on the important role the business enterprise plays in searching for and/or developing new opportunities, either at home or abroad. Nor did they feature learning or leadership. Rather, the evolution of the enterprise (including the MNE) is due, in these frameworks, to management's desire to minimize transaction costs, and in particular to guard against opportunism. Opportunity, on the other hand, is almost completely neglected.

Organizational change is also missing. What limited change there is - Williamson's "fundamental transformation" being perhaps the main exemplar is not due to entrepreneurship or innovation. Rather, it arises from past investments that are "held up" (i.e., rent is extracted) because of extortionate recontracting by opportunistic contractual partners who take advantage of changes in bargaining positions once idiosyncratic investments have been made.

Put differently, internalization theories, to the extent to which they rely on Coase and Williamson, posit ubiquitous contractual problems, which in turn lead to "market failures". Internalization overcomes these problems primarily by changing governance structures. Entrepreneurial and managerial functions such as opportunity discovery, learning, and knowledge creation play almost no role in their analyses. Neither entrepreneurship nor leadership is needed or featured.

In reality, however, entrepreneurs and entrepreneurial managers working in an organizational context discover and create new knowledge and help commercialize new technologies at home and abroad. They learn about new opportunities, and sometimes help create them and transfer technologies as needed. Because the market for information/ knowledge about new opportunities (Gans \& Stern, 2010; Teece, 1981b) isn't well developed, entrepreneurs and managers must build organizational capabilities inside businesses firms to assist in knowledge creation and knowledge capture (Teece, 1986b, $2006 \mathrm{~b}$ ). To be effective, such firms often need to be global in scope. The neglect of these entrepreneurial/ managerial functions in the theory of the firm would appear to be a serious omission. ${ }^{23}$ The neglect of the role of the leader, particularly in organizational transformation, is equally serious.

\section{"Control" Follows Ownership of (Foreign) Subsidiaries; Inter-Firm Relationships Enigmatic} Most "governance"-based theories of FDI implicitly assume, or explicitly state (e.g., Hennart, 2010), that strategic control comes through ownership and resides with the parent, that getting incentives right is not only necessary but sufficient to achieve alignment of goals and economic efficiency, and that subsidiaries are just that. In isolation, and putting financial constraints to one side, this view of the MNE tends to see the wholly owned subsidiaries as the preferred organizational form, because protecting specific assets from recontracting hazards is the main purpose of the MNE. ${ }^{24}$

In reality, the common ownership of business units doesn't eliminate incentive problems, nor does it necessarily achieve control. This is particularly true in the MNE context, where the identification of host countries' employees with the MNE shareholder is less than perfect. This is well recognized by international business scholars; but the internalization theory of the MNE struggles to find an elegant way to take this into account. If asset ownership is neither necessary nor sufficient for incentive alignment, as Helper and Sako (2012) suggest, then internalization theory must somehow be modified if it is to capture the essence of the MNE. Certainly, evidence that MNEs choose to internalize in order to guard against recontracting hazards is weak at best. ${ }^{25}$

The business historian Alfred Chandler was one of the first to identify the structural virtues of a fully integrated firm that was global in scope. In his paradigm, (vertical) integration was necessary to achieve coordination (Chandler, 1977). However, cross-border communication technology has improved dramatically in recent decades, and capabilities are more globally dispersed than ever. As a result, coordination in the supply chain seems to be less dependent on internalization than it once was. The implications for internalization theories are considerable.

Consider Apple, which is known for the ingenuity of its designs, yet it owns none of its own manufacturing. It has tight supply relations with many companies - some pure contractors (e.g., Foxconn, headquartered in Taiwan with factories in China) and at least one competitor (Samsung, headquartered in Korea). Apple helps provide financing to some of its suppliers, and may obtain exclusive purchase 
arrangements from them for short periods (e.g., three years). Contractual arrangements appear to suffice for Apple to achieve the necessary coordination, while retaining the flexibility needed to respond to market forces. Powerful examples of heavily outsourced companies, such as Apple, serve to remind us that standard contractual approaches to internalization need to be combined with, and arguably embedded into, entrepreneurial, capability, and "network" paradigms of the firm.

These outsourcing arrangements have been studied under several names, including "international production networks" (e.g., Ernst \& Guerrieri, 1998) and "global value chains" (e.g., Gereffi, Humphrey, $\&$ Sturgeon, 2005). Buckley introduced the expression "global factory" to characterize a network in which "Brand owners will control design, engineering and marketing while outsourcing large areas of production to parts suppliers and they may well contract out final assembly" (Buckley, 2007: 115). Buckley claims that his global factory network is "held together by control of key assets and flows of knowledge and intermediate products" (Buckley, 2009: 230). The global (virtual) factory concept appears to be the structure selected by Buckley to accommodate notions of dynamic capabilities.

\section{Competitive Advantage Neglected}

As Geoffrey Jones notes, "the recognition that multinationals are profoundly heterogeneous is one of the most important lessons from history" (Jones, 2005: 289). The theory of the multinational firm in economics - and transaction cost theory is no exception - does not deal effectively with this heterogeneity, and hence cannot address issues relating to competitive advantage, that is, the foundation for enterprise- or business-level financial performance that is both superior ("supernormal") and durable. While different governance forms are seen as suitable for certain transaction types, the framework is silent as to how competitive advantage is built and preserved for particular firms. It is true that the invention of new and superior governance modes can be a source of temporary competitive advantage, but, as a general matter, there is no easy way to protect innovations in governance from rapid imitation. Hence, governance advantages will erode, sometimes rather quickly.

Moreover, thanks to the very development of transaction cost economics and its wide dissemination, knowledge of the tools of good governance is available in the public domain. Adoption of good governance protocols may of course be impaired by factors inside the enterprise. If so, new governance modes may serve to create differentiation. But transaction cost analysis does not contribute significant insights into when and where this is the case. Accordingly, it is of limited relevance to scholars and practitioners seeking an understanding of competitive advantage.

Neglect of firm-level heterogeneity and the particulars of competitive advantage is perhaps the primary reason for the schism between the fields of international business and international (strategic) management. The former largely ignores it; the latter embraces it. Until this chasm is bridged, international business scholars will have little to say to managers, and international management scholars will have little to contribute to public policy or the understanding of national competitiveness.

\section{TOWARD A CAPABILITIES THEORY OF THE MNE}

\section{Antecedents: Resources and Early Capabilities Perspectives}

Internalization theories have yielded important insights into the MNE. This is true with respect to both prongs of the approach. However, as the international business field has matured, and as the theory of the firm in economics has evolved, relatively neglected (capabilities-related) factors now seem more salient. My early efforts to understand international technology transfer, which were made under the internalization rubric (e.g., Teece, 1976, 1977a), used elements of a capabilities story that transcended transaction costs. However, in these early treatments, capabilities considerations were soon swamped by contractual concerns (Teece, 1985, 1986a). This needs to be readdressed in my own work, as well as in the literature at large.

A capability is the capacity to utilize resources to perform a task or an activity, against the opposition of circumstance. Essentially, capabilities flow from the astute bundling or orchestration of resources. The organizational and managerial "technology" of the firm and its ability to transfer technology (embedded in routines and resources) across distances and borders are very much implicated in the firm's national and global capabilities.

The (dynamic) capabilities framework is an entrepreneurial approach that emphasizes the importance of (signature) business processes, both inside the firm and also in linking the firm to external partners. It also recognizes the importance of critical resources and good strategy. It is not animated primarily by transaction cost or contractual concerns. Rather, it 
builds on the resource-based approach. It is focused more on opportunity than on opportunism, and on the efficient and effective transfer of technology between and among the various organizational units of the firm.

Teece $(1980,1982)$ explored Penrose's ideas of resource fungibility by assessing how the nature of a resource, and in particular its "tradability" (or lack of it), affected diversification. A firm with excess factor services (i.e., above those needed for its current and projected production program) may find it more profitable to monetize those services via a new use rather than through a market transaction. While this research focused on product diversification, it was also applicable to international diversification.

What has been missing is systematic attention to how (entrepreneurial) management can deploy or redeploy the nontradable assets and resources at its disposal. Wernerfelt (1984) and Barney (1991) began the task of filling this gap, building on Penrose's view that making better use of resources was important to enterprise growth and development. Penrose herself viewed entrepreneurship as one of the resources of the firm, stating, "[W]e include "entrepreneurs' among the resources of the firm and the range of ideas of entrepreneurs among the services rendered" (Penrose, 1959: 86). In this regard, she was perhaps describing a dynamic capability, at least in the sense referred to here.

Despite Penrose's abiding interest in the international firm, she did not pay particular attention to the application of her theory to the case of the MNE (Pitelis, 2007). Moreover, although Penrose did recognize the importance of entrepreneurship, she did not fully address the roles of entrepreneurs in designing business models or organizations (Augier \& Teece, 2007), or in building competitive advantage. Rather it was Wernerfelt $(1984)$ and Barney $(1986,1991)$ who articulated the relationships among firm resources and competitive advantage. They focused on the possession of the right resources as the main mechanism for the generation of economic rent. The resources to worry about were defined by Barney (1991) as those meeting his criteria of valuable, rare, inimitable, and non-substitutable (VRIN). Implicitly, Barney was inviting strategists to focus on intellectual capital (Teece, 2000), since this is the class of assets that most frequently meets the VRIN criteria.

As already noted, Teece $(1976,1977 \mathrm{a})$ and Cantwell (1989) early on had threads of a resource and capabilities approach under development. This initially manifested itself as a knowledge-based approach to the MNE with Teece $(1981 a, 1981 b)$ and
Kogut and Zander (1992, 1995). However, knowledge-based approaches - which emphasize how the generation and transfer of knowledge, along with transaction cost problems in the market for knowhow, dictate integration and/or foreign ownership are insufficiently robust to capture many relevant entrepreneurial and capabilities features. Interestingly, recent work in international business (some of it generated by advocates of the transaction-costbased or exchange-based paradigm) has already begun to focus on an entrepreneurial/capabilities approach (e.g., Buckley, 2009; Casson, 2000, 2005; Dunning \& Lundan, 2010; ${ }^{26}$ Pitelis, 2004; Pitelis \& Teece, 2010; Rugman \& Verbeke, 2003). It is now time to carry these efforts forward on a comprehensive basis into a (dynamic capabilities-based entrepreneurial) theory of the MNE. ${ }^{27}$

A robust theory of the MNE that explains its scope, its boundaries, and the role of subsidiaries, while also providing insights into the competitive advantage of particular MNEs, requires that the entrepreneurship, resources, and capabilities concepts be somehow amalgamated. The (dynamic) capabilities approach, advanced in the field of strategic management and applied below in the context of the MNE, endeavors to do so, and is the subject matter of most of the remainder of the paper. The goal is to help shape a more robust theory of the MNE that highlights how firm-level sustainable (durable) competitive advantage is both built and maintained.

Understanding sustainable competitive advantage (and not just the boundaries of the firm) is a broader mandate for a theory of the MNE than what internalization scholars typically accept. Coming up with a better theory of the MNE that does double duty (i.e., explains boundaries and competitive advantage) requires a comprehensive, multidisciplinary approach to understanding managerial decisionmaking and business organization in a context where intangible assets are important, and where there are rapid changes, frequent discontinuities, and great complexity, engendered in part by the fact that the world's needs and desires have not (yet) become irrevocably homogenized. ${ }^{28}$ Labor is not fully mobile, and many national institutions remain distinct. The world is, and is likely to remain, only semiglobalized (Ghemawat, 2003). It is this world of firm-level heterogeneity and semiglobalization - and not the hypothetical worlds of perfect competition or oligopoly - that animates the inquiry here.

The capabilities framework resonates well with Cantwell's (1989) work. ${ }^{29}$ Cantwell recognized, correctly, that a theory of the MNE based on an exchange 
(or transaction cost/governance) framework masks any active role for management (Cantwell, 1989: 215). He also argued that ownership advantages are endogenous and developed through innovation and strategy, and showed how MNEs extend their capabilities and their overall innovation potential using global networks.

The capabilities perspective can also be seen as consistent with other international business literature, including recent thinking on knowledge management in a networked MNE (e.g., Rugman \& D'Cruz, 2000; Rugman \& Verbeke, 2001, 2002, 2003; Vahlne \& Johanson, 2013). As noted earlier, some knowledge-based theories of the MNE can be thought of as special cases of a resources/capabilities theory of the MNE. An essential characteristic of organizations/firms is that they can generate and embody knowledge, which can't be easily bought and sold. Sometimes the only way to capitalize on knowledge is to start a firm and build the necessary complementary assets (Teece, 1986b, 2006b). To fully capitalize on opportunities, such firms must often be global from the beginning. In short, capabilities generally have to be built, as they cannot be bought.

The dynamic capabilities framework developed below goes beyond the knowledge and technological elements highlighted in earlier research to more explicitly include managerial and organizational capabilities as determinants of competitive advantage. It contends that the active development and astute orchestration of tangible and intangible assets by both parent and subsidiaries lie at the heart of the rationale for the MNE and, together with strategy, determine its longer-run success. ${ }^{30}$

\section{Definitions and Core Building Blocks}

The original definition of dynamic capabilities by Teece, Pisano, and Shuen (1997: 516) referred to the ability of an organization and its management to integrate, build, and reconfigure internal and external competencies to address rapidly changing environments. ${ }^{31}$ Eisenhardt and Martin (2000) extended this to also embrace what I refer to as "shaping the environment".

Teece et al. (1997) identified the core building blocks of dynamic capabilities under the tripartite rubrics of processes, positions, and paths. This was supplemented in Teece (2007) by a more applied focus organized around sensing, seizing, and transforming. In what follows, I relate the two taxonomies, and then show how strategy fits in. Important clarifying distinctions between ordinary and dynamic capabilities are made. Application to the MNE follows.

\section{Processes}

Teece et al. (1997) identified three classes of processes/ managerial functions that are relevant to dynamic capabilities under the following rubrics: coordination/integration; guided learning; and reconfiguration/transformation. Organizational processes embed the strategy and business model of the business into the day-to-day routines of employees. The effectiveness of organizational routines is buttressed by strong and consistent organizational values.

Dynamic capabilities thus reside, at least in part, in the managerial, entrepreneurial, and leadership skills of the firm's top management, and in management's ability to design, develop, implement, and modify these routines. Either way, firms with superior dynamic capabilities have learned to adjust to changing environments, and also to shape the (business) environment.

\section{Positions (resources) 32}

As noted earlier, the asset positioning of a company matters. I am referring not just to balance sheet assets (plant and equipment and the like) but also to human capital and knowledge assets. Teece et al. (1997) identified technological assets, complementary assets (technological or otherwise), financial assets, reputational assets, market structure assets, and institutional assets. It is obvious that a road construction company will need access to heavy equipment (e.g., bulldozers and dump trucks), and a home-building company will need access to architectural services, as well as construction tools and skilled and unskilled labor. A bank will need financial assets, and the talent to build and run systems for loan origination and underwriting, etc.

The firm's position, as defined by its resources, is enhanced if the resources meet Barney's VRIN criteria. As I have noted elsewhere (Teece, 2000), the class of assets most likely to satisfy VRIN criteria is intellectual capital, particularly technology and know-how. Intellectual capital readily meets most of the VRIN criteria because it tends to be tacit and idiosyncratic, and has fuzzy edges. In essence, the criteria distinguish between ubiquitous resources available to all at competitive prices and those that are more specific or unique. Furthermore, the VRIN criteria recognize that a unique asset is not valuable for its own sake. It delivers value to the firm and its stakeholders only if it supports a point of difference that is appealing to the customer, and which, 
furthermore, cannot easily be replicated by others with different assets.

Needless to say, it should be immediately apparent that, in fast-paced competitive environments, positions/resources alone are generally of fleeting value. The way assets need to be deployed (usually in clusters or combinations) is likely to be dynamic and involve astute and entrepreneurial "orchestration" activity by management. As noted in Teece et al. (1997: 515):

\footnotetext{
The global competitive battles in high-technology industries... have demonstrated the need for an expanded paradigm to understand how competitive advantage is achieved. Well-known companies... have followed a "resource-based strategy" of accumulating valuable technology assets... However, this strategy is often not enough to support a significant competitive advantage.
}

Clearly, the manner in which assets and other resources are coordinated and orchestrated is at least as important to competitive success as the identity of the assets themselves. This is where asset orchestration and market creation (or co-creation) come into play (Pitelis \& Teece, 2010). Whereas neoclassical and transaction cost economics assume that markets exist, even if they don't function well, the capabilities approach makes no such assumption. Markets may have to be created, in the sense that new products and services are introduced for which after-sales support and product training, for instance, may be lacking and may have to be built. This is what Singer did globally to allow market development of the sewing machine. In India, Gillette has likewise been promoting the benefits of removing beards in order to broaden the market for its safety razors. The need for such creation activities to expand markets is assumed away in transactionbased approaches, where there is almost always a party (or customer) to transact with. This reduces the problem to one of contracts, when in fact the fundamental problem may be one of market existence or market expansion.

The problem stems in part from what was referred to earlier as the equilibrium assumption. In a "perfect" world of markets (spot, term, future, etc.), the firm has full information about competitors, about complementors in investment decisions, and about what consumers really want. But, in reality, much of this information is proprietary, tacit, or diffuse, and thus inaccessible. The decision to invest depends on sensing an opportunity and also on sensing how potential competitors and complementors will respond. This is not a capability required in a neoclassical world of perfect competition.
The focus of the dynamic capabilities framework is on how firms can create, extend, integrate, modify, and deploy their resources and/or specific assets while simultaneously managing competitive threats and effectuating necessary transformations. ${ }^{33}$ Whereas other approaches emphasize tangible asset/resource ownership and protection, the dynamic capabilities perspective emphasizes intangible assets and resource augmentation, and also asset orchestration.

By embedding (managerial) asset orchestration into the theory of the MNE, the field of international business can build bridges to topics in international management.

\section{Paths (strategy)}

It is important to recognize that strategy must go hand in hand with processes, resources (positions), and capabilities. Strategy, when developed successfully, involves deploying the firm's scarce assets to support market needs and gain advantage over rivals, while recognizing market and technological opportunities and any constraints imposed by the firm's historical path of evolution.

Put differently, the managerial orchestration that is core to enhancing processes and exploiting positions must be guided and informed by strategy - and vice versa. ${ }^{34}$ Strategy needs to be consistent, coherent, and embrace innovation. While it is necessarily shaped by the legacy of the past, it also shapes the path ahead. Strategy will determine which products to make, which customers to target, how to deploy the firm's resources, what the optimal timing will be, and how to keep competitors at bay.

A strategy can be defined as "a coherent set of analyses, concepts, policies, arguments, and actions that respond to a high-stakes challenge" (Rumelt, 2011: 6). A good strategy has:

(1) prescient diagnoses;

(2) a guiding policy; and

(3) coherent action.

These three functions constitute what Rumelt (2011) calls the "kernel of strategy". ${ }^{35}$ A good strategy will often not appear fully formed, but instead emerge after a period of trial and error (provided the business environment is sufficiently forgiving to allow experimentation). While the actions dictated by the strategy may be visible to rivals, and freely imitable, rivals may not perceive it in their interest to do so until it is too late, because the underlying diagnosis and policy can be kept secret.

In the framework advanced here, dynamic capabilities and business strategies codetermine 
performance. ${ }^{36}$ Firms with weaker capabilities will require different strategies from firms with stronger capabilities. Strong dynamic capabilities require firms to sense, seize, and transform in conjunction with a sound strategy. A sound strategy must in turn have a strong kernel.

For purposes of operationalizing the framework, dynamic capabilities can usefully be disaggregated into three clusters of processes and entrepreneurial/ managerial orchestration activities conducted inside firms (Teece, 2007):

(1) identification and assessment of opportunities at home and abroad (sensing);

(2) mobilization of resources globally to address opportunities, and to capture value from doing so (seizing); and

(3) continued renewal (transforming).

These activities are required of the firm's management if the firm is to sustain itself as markets and technologies change. In a global context, the MNE's management must not only be entrepreneurial, but also cosmopolitan, or what Perlmutter (1969) called "geocentric".

It is important to emphasize that the framework advanced here sees the effectiveness of dynamic capabilities as being compromised by poor strategy. Strategy and dynamic capabilities can be seen as analytically distinct concepts, although they are in practice interrelated (Table 1). For instance, sensing is important to dynamic capabilities but also contains a strong element of diagnosis, which is important to strategy; seizing needs to be connected to both a guiding policy and coherent action; and transforming that is value protecting and enhancing requires a guiding policy and coherent action. The nature of the managerial tasks for various elements of strategy is outlined in Table 1. Entrepreneurial management is especially relevant to the firm's ability to be prescient and sense opportunities and threats (both market- and technology-related).

\section{Replicability and Imitability: Ordinary vs Dynamic Capabilities}

In the dynamic capabilities framework, considerable emphasis is placed on the replicability and imitability of organizational processes and positions (Teece, Pisano, \& Shuen, 1997). Clearly, if one is interested in sustainable competitive advantage, one needs to take imitability into account. That which is easily replicated by the firm is scalable, possibly globally. ${ }^{37}$ However, that which is easily imitated by others will clearly not be able to support superior financial returns. When examining competitive advantage, it is therefore critical to distinguish between "ordinary" (and easily replicable) capabilities and dynamic capabilities, which by their very nature are hard to replicate. As explained below, ordinary capabilities support technical fitness, while dynamic capabilities support evolutionary fitness. The former is about the enterprise "doing things right;" the latter has more to do with "doing the right things".

\section{Ordinary capabilities: Foundations}

It is perhaps easier to understand what dynamic capabilities are as a class by juxtaposing them against ordinary capabilities. ${ }^{38}$ Ordinary capabilities can be broken into operational, administrative, and governance capabilities (Teece, forthcoming). Here I emphasize that ordinary capabilities are about producing and selling a defined (and static) set of products and services. The degree of proficiency, however obtained, indicates the strength of the ordinary capability, for which practice often makes perfect.

Ordinary capabilities simply allow an existing product or service to be made, sold, and serviced. They will not necessarily permit the MNE to grow except in environments with low competition, no technological disruptions, and very limited globalization. ${ }^{39}$ When local capabilities in jurisdictions where MNEs operate are weak relative to those the MNE can transfer to an affiliate, ordinary capabilities may nevertheless allow an MNE to possess competitive advantages for indefinite periods.

Ordinary capabilities and their diffusion matter to the MNE. ${ }^{40}$ They undergird the MNE's technical fitness. Technical fitness ${ }^{41}$ supports static efficiencies; but unless competition is very weak, and demand is strong, ${ }^{42}$ ordinary capabilities are unlikely to support durable competitive advantage. Such capabilities allow an organization to keep "earning

Table 1 The interrelation of dynamic capabilities and strategy

\begin{tabular}{llll}
\hline Strategy kernel & Diagnosis & Guiding policy & Coherent action \\
\hline Related dynamic capabilities clusters & Sensing & Seizing/Transformation & Seizing/Transformation \\
Nature of managerial orchestration & Entrepreneurial & Administrative & Leadership \\
\hline
\end{tabular}


its living by producing and selling the same product, on the same scale and to the same customer population over time" (Winter, 2003: 992).

Ordinary capabilities enable the firm to perform definable tasks. They rest on (1) non-VRIN resources and (2) practices, even best practices. The level of ordinary capabilities can therefore be measured against a particular task or standard. "Best practice", in a sense, does precisely that. ${ }^{43}$ Best management practices, for example, can be thought of as those that "continuously collect and analyze performance information, that set challenging and interlinked short- and long-run targets, and that reward high performers and retrain/fire low performers" (Bloom, Genakos, Sadun, \& Van Reenen, 2012). ${ }^{44}$ Many best practices, however, diffuse rather quickly in a world where everyone has access to similar benchmarks. Bob Lutz (2011), the former vice chairman at General Motors, illustrates this point for the automotive industry:

\begin{abstract}
The operations portion of the automobile business has been thoroughly optimized over many decades, doesn't vary much from one automobile company to another, and can be managed with a focus on repetitive process. It is the "hard" part of the car business and requires little in the way of creativity, vision or imagination. Almost all car companies do this very well, and there is little or no competitive advantage to be gained by "trying even harder" in procurement, manufacturing or wholesale.
\end{abstract}

This statement is revealing, as it indicates how best practices, hence ordinary capabilities, are widely distributed, at least in the global automotive industry. ${ }^{45}$ If so, they can no longer be the foundation of competitive advantage, as elaborated below.

\section{Ordinary capabilities: Replication and transfer.}

What undermines the power of ordinary capabilities to serve as the foundation of competitive advantage for a particular MNE is that such capabilities can be imitated much more easily today than in earlier times. A good deal of know-how, which used to be tacit and proprietary just two or three decades ago, is now explicit and in the public domain - available from consultants, schools of engineering, and the public literature. ${ }^{46}$ Explicit (codified) knowledge travels easily, and the Internet, by allowing low-cost access to information, has helped enable this. The implication is that the barriers to the transfer of ordinary capabilities have been dramatically reduced in recent decades.

Indeed, many basic business services (e.g., accounting, sales, human resource management) can today be readily outsourced to computing resources resident in the "cloud". ${ }^{47}$ These developments enabled by Internet protocols, the general march of computer-processing power, and the growth of "fat clients" - greatly facilitate starting up, as well as running, a business. Many routine operational and administrative capabilities can be supported remotely by independent providers. Hence, they are no longer as critical to competitive advantage. For example, the implications of "cloud computing" for the MNE are profound. In short, the Internet facilitates the availability of ordinary capabilities not just because of low cost and easy access to the flow of information, as Richard Nelson has emphasized, ${ }^{48}$ but because of low cost and easy access to the computing, software resources, and data storage needed to support basic, yet high-quality, business functions.

Knowledge transfer within an organization presents a host of difficulties (Szulanski, 1996). And replicability does not always imply imitability. Knowledge may remain difficult for external organizations to replicate to the extent that it is embedded in interactions among people, tasks, and tools (Argote \& Ingram, 2000).

Notably, MNEs investing abroad "appear to adopt good management practices in almost every country in which they operate" (Bloom et al., 2012: 14). Indeed, Bloom et al. found that foreign multinationals are generally better managed than hostcountry firms. MNEs may thus succeed for a while with strong ordinary capabilities, because ordinary capabilities developed at home may temporarily be distinctive abroad. ${ }^{49}$

Some less-developed economies still lack domestic firms performing what, from a developed-country perspective, would be thought of as mundane tasks. Yum! brand's success in China, for example, appears to be due in large part to its ability to transfer and adapt ordinary capabilities (Starvish, 2011). This adaptation is itself partially a dynamic capability.

Another "barrier" to imitation is the simple failure of rivals to implement publicly available best practices (Knott, 2003). Bloom et al. (2012: 13) found in their study that there is a wide dispersion with respect to good management practices within every country and across countries, as shown in Figure 1. In a survey of more than 10,000 organizations across 20 countries, they also found that foreign MNEs were generally better managed (i.e., they had better ordinary capabilities) than domestic firms (Bloom et al., 2012: 23). Brazil and India had a large tail of very badly managed firms. 


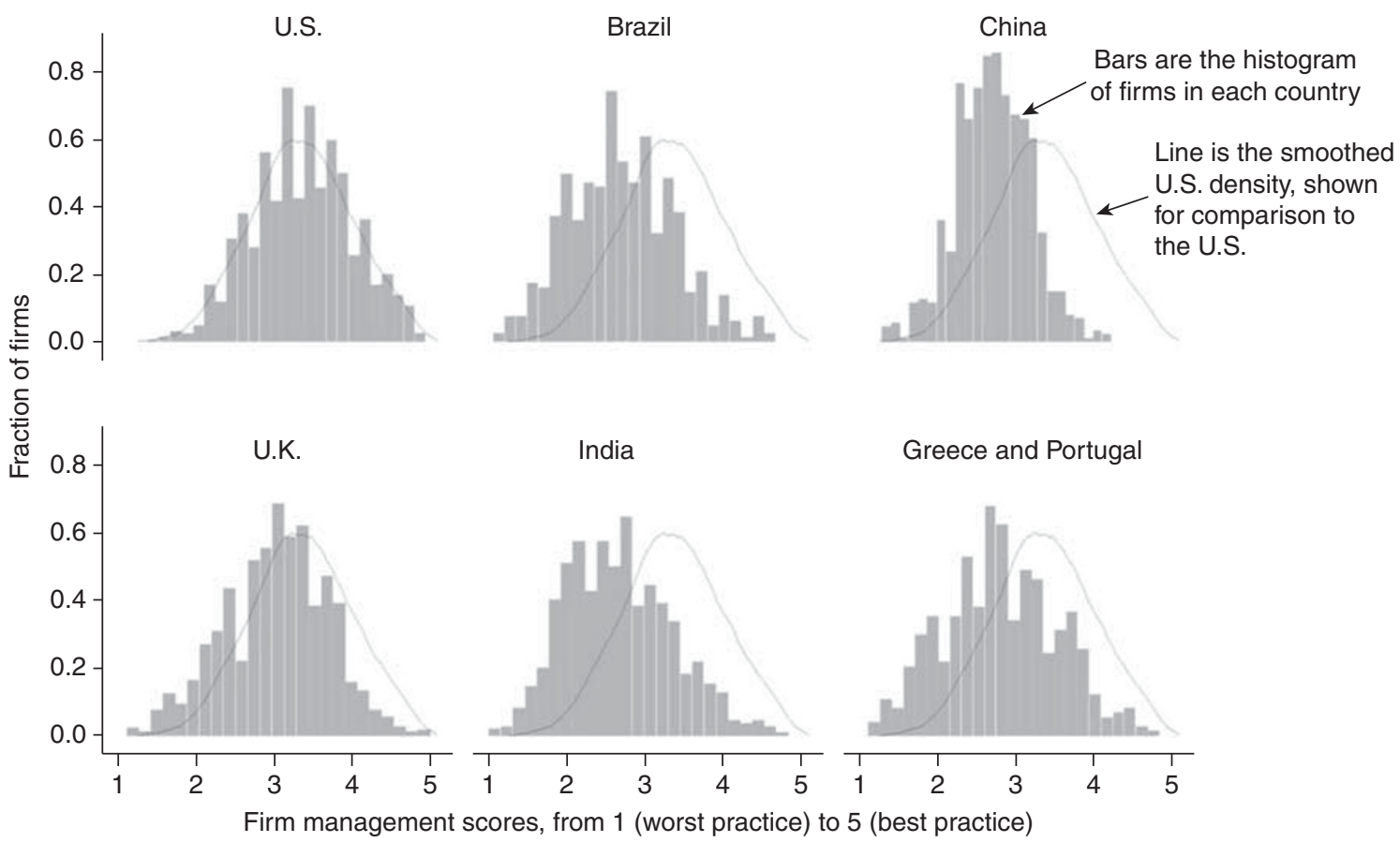

Figure 1 Best-practice diffusion.

Source: Bloom et al. (2012).

Nevertheless, competition and imitation will, over time, lead to the erosion of any advantage from ordinary capabilities. This may occur slowly, but can be rapid in contexts where the absorptive capacity of external organizations is high. An MNE subsidiary relying solely on strong ordinary capabilities in a particular host country will find, if the ordinary capabilities are imitable (e.g., via knowledge spillovers through employee turnover) and competitors can enter, that its advantage will steadily diminish. In short, ordinary capabilities will not support long-run competitive advantage unless competition is suppressed by governmentally or privately imposed entry barriers, or by weak physical and social infrastructure that prevents ordinary capabilities from quickly diffusing throughout the economy.

\section{DYNAMIC CAPABILITIES: ASSESSMENT}

Since the late 1970s, local differentiation, global integration, and innovation have characterized successful firms operating globally. In the global economy today, the competitive advantage of the business firm appears to rest on the development and deployment of intangible assets, ${ }^{50}$ relationships, and human capital. These developments have placed a premium on the ability of companies to become entrepreneurial and agile at home and abroad, requiring in turn that management operate with less authority, and organize to allow and promote flexibility, responsiveness, and learning. This requires dynamic capabilities.

As already noted, dynamic capabilities are undergirded by processes (routines) and resources (positions). Dynamic capabilities rely not just on best practices but on "signature" practices; not just on any resources but on VRIN resources. They also require astute managerial orchestration guided by what Rumelt (2011) has called "good strategy". Table 2 illustrates this, and contrasts it with ordinary capabilities.

Signature processes and signature business models are beyond industry best practices. Such processes embody a company's history, experience, culture, and creativity (Gratton \& Ghoshal, 2005). Because of their deep roots, they are not so easily replicated by others who do not share this history, and may have different values, too. Over longer periods of time, such processes and business models may become somewhat imitable by others. As Gratton and Ghoshal point out, such a transformation occurred with Toyota's lean manufacturing model, the Toyota System of Production.

Whether signature processes and business models are "good" may take some time to become apparent. Eventually, it should show up in key performance 
Table 2 Elements of the capabilities framework

\begin{tabular}{llll}
\hline Core building blocks & Weak ordinary capabilities & Strong ordinary capabilities & Strong dynamic capabilities \\
\hline Processes (routines) & Sub-par practices & Best practices & Signature practices and business models \\
Positions (resources) & Few ordinary resources & Munificent ordinary resources & VRIN resources \\
Paths (strategy) & Doing things poorly & Doing things right & Doing the right things (good strategy) \\
\hline
\end{tabular}

indicators. However, the replicability of a process or business model is often confounded, particularly externally, by what Lippman and Rumelt (1982) call "uncertain imitability". This, along with a high tacit component to the underlying knowledge, may keep a signature process effectively proprietary.

There is an obvious opportunity for all business enterprises to learn, and to embed that learning in new signature processes and business models. Hence the MNE competing in diverse contexts has the opportunity to develop distinct signature processes and models in different geographies. Accordingly, the MNE as such may have an advantage in the development of new products and signature processes and models, as it can more readily run multiple, simultaneous experiments than can a pure domestic enterprise. Moreover, adaptation and adoption of new processes inside the MNE are likely to be easier than they would be across unaffiliated enterprises. Certainly, top management can endeavor to drive such adoption inside the company.

A corollary of the fact that VRIN resources and signature processes and business models are products of the firm's heritage and past managerial decisions is that dynamic capabilities tend to get built, are difficult to imitate, and cannot generally be bought. For example, Tim Cook, a long-time executive at Apple and its current CEO, said in February 2013: "Apple has the ability to innovate in all three of these spheres and create magic... This isn't something you can just write a check for. This is something you build over decades" (AFP, 2013). This is the reason for the "stickiness" of dynamic capabilities - that is, they don't tend to travel well, they are complex, and they are hard to figure out and to implement.

Once again, Bob Lutz (2011) of General Motors put it most succinctly:

Where the real work of making a car company successful suddenly turns complex, and where the winners are separated from the losers, is in the long-cycle product development process, where short-term day-to-day metrics and the tabulation of results are meaningless.
Dynamic capabilities also help characterize how an enterprise obtains strengths, extends these strengths (for instance by developing new business models), synchronizes business processes and models with the business environment, and/or shapes the business environment in its favor (Teece et al., 1997). They are higher-order, difficult-to-replicate capabilities. Asset orchestration is implicated, and dynamic capabilities support the firm beyond merely achieving superior "coordination". They are based on processes that are beyond best practice, and on resources that meet the VRIN criteria.

Firms with strong dynamic capabilities exhibit technological and market agility. To achieve this, they use less hierarchy. Agility, coupled with the ability to sense new opportunities and threats, supports evolutionary fitness. ${ }^{51}$ This inevitably requires that firms constantly create new technologies, differentiated and superior processes, and better business models to stay ahead of the competition, stay in tune with the market, and even shape the market if necessary. ${ }^{52}$ The firm must be able to simultaneously cope with changes in the external environment and with changes caused by processes internal to the firm (Greiner, 1998). ${ }^{53}$ It will be aided if it has sufficient resources and superior information, talent, and capital, including relationship capital. However, absent the required ability to orchestrate resources, and to create and execute a quality strategy, such resources are likely to be of little value.

As noted, strong dynamic capabilities will help organizations to stay relevant to marketplace needs and technological opportunities. Organizations must change their capabilities to reflect anticipated changes in markets, technologies, and the business environment more generally. However, as Winter explains, change can be reactive - firms can easily get into a "fire fighting" mode, which he describes as "high paced, contingent, opportunistic and perhaps creative search for satisfactory alternative behaviors". Winter (2003: 993) called this "ad hoc problem-solving". This is in contrast to routinedirected problem-solving. In Winter's terminology, the latter is a capability. He correctly recognized 
that it is possible that on close examination even "fire fighting" approaches to problem-solving may have micro-routines embedded within. Certainly, skills are implicated.

The individual and organizational skills at issue with dynamic capabilities are much more oriented to creating unique problem-solving methodologies and signature processes. Problem-solving is very much a dynamic capability. ${ }^{54}$ There is much distance between the purely routinized and that which is purely ad hoc. The middle ground also constitutes a (dynamic) capability. Indeed, most invention isn't fully directed. The innovation process is neither completely routinized nor ad hoc.

The capabilities approach, expanded upon below, sees MNE activity as driven by the opportunity to leverage capabilities and create and capture value from innovation on a global scale. Entrepreneurial managers are not just resource allocators; they also sense, shape, and exploit opportunities. A theory of the (multinational) firm that doesn't recognize this logic and these phenomena, and their associated locational dimensions, will be unable to explain the MNE's sustainable competitive advantage. ${ }^{55}$

To create and exploit opportunities globally, entrepreneurial activity must be linked up with capital and other complementary assets, because property rights over discoveries and inventions are incomplete. Some ownership and control over complementary assets is likely to be needed to assist the
MNE in the appropriation of value needed to support continued investment (Teece, 1986b, 2006b). As explained in Teece (1980, 1982, 1986b), managers, entrepreneurs, and innovators cannot just leave it up to the market to line up specific assets and develop new ones, and integrate them into a well-functioning global invention, production, and marketing system that provides the theoretical raison d'être and management for the MNE. They are themselves the instruments that make markets work well. Even if Coasian transaction costs were zero, learning, co-creation, and orchestration functions would still need to be carried out. The entrepreneurially managed MNE is a vehicle designed to do so.

The firm is indeed, as Coase (1937: 388) noted, an island of conscious power - but it is unsatisfactory to frame managerial capacity primarily in transaction cost-minimizing terms, as Coase asserted. Rather, the functions of management can be framed in terms of assisting in the building and/or securing and deploying of VRIN resources and signature processes not typically available for sale (or, if available, not routinely priced in a liquid market). The business firm is an island of (non-market) resource allocation orchestrated to enhance learning, value creation, know-how transfer, and value capture. These factors help explain why it is necessary to transform internalization theory into an entrepreneurial/capabilities theory of the MNE. The economic logic of the framework is reflected in Figure 2.

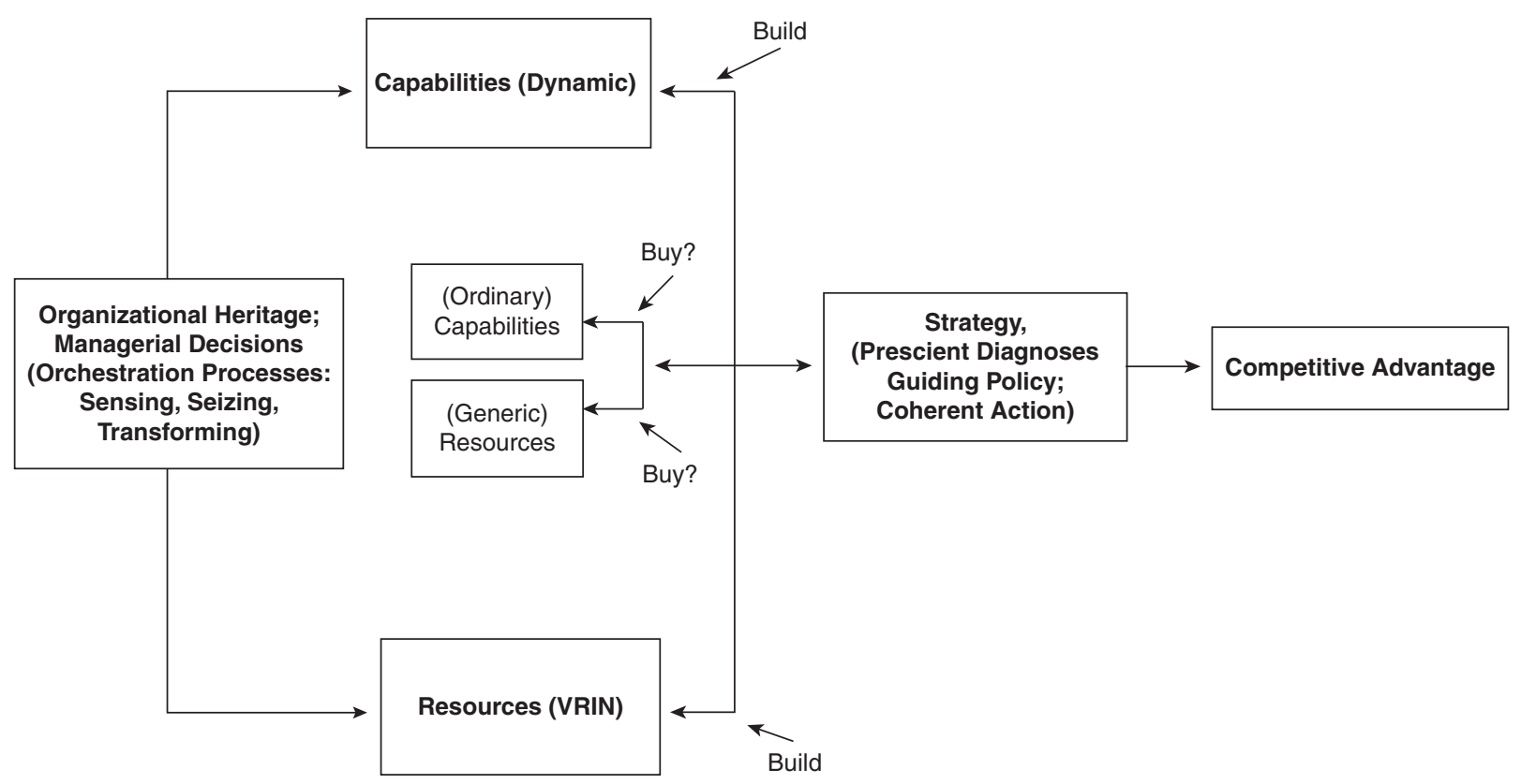

Figure 2 Logical structure of the dynamic capabilities paradigm. 


\section{CAPABILITIES AND MNE PERFORMANCE}

While ordinary capabilities are insufficient for longterm survival and growth, dynamic capabilities enable the firm to have a better chance of establishing and maintaining competitive advantage (and concomitant superior performance) in economies where change is rapid, and intangible assets are critical to competitive differentiation. ${ }^{56}$ However, as indicated in Figure 2, the firm also needs good strategy.

Dynamic capabilities are hard to develop, and difficult to transfer across borders, in part because they are tacit, in part because they are often embedded in a unique set of relationships and histories, and in part because of uncertain imitability. In short, dynamic capabilities undergird the "future" of any MNE, because, along with strategy, they undergird competitive advantage in fastmoving, knowledge-based economies. They often lie at the heart of both short- and long-cycle product development processes.

Bartlett and Ghoshal (2002: 14) noted that "as major global competitors achieve parity in the scale of their operations and their international market positions, the ability to link and leverage knowledge is increasingly the factor that differentiates the winners from the losers and survivors". These authors were tilting toward elements of a dynamic capabilities framework, because such a framework is also about linking and leveraging know-how. Good strategy, strong ordinary capabilities, scale (in some circumstances), and strong dynamic capabilities are all needed for long-term growth and survival in the framework advanced here.

As noted, ordinary capabilities are about doing things right, whereas dynamic capabilities are about doing the right things, at the right time, based on unique processes, organizational culture, and a prescient assessment of the business environment and technological opportunities. ${ }^{57}$ By the right things, I refer to investment in new products, processes, and business models that are in tune with the firm's business environments at home and abroad, and with its strategy. The late Steve Jobs made a strong statement with respect to the importance of spending money on the right things:

Innovation has nothing to do with how many R\&D dollars you have. When Apple came up with the Mac, IBM was spending at least one hundred times more on R\&D. It's ... about ...how much you get it. (cited in Kirkpatrick, 1998)

"Getting it" requires strong dynamic capabilities. The dynamic capabilities perspective goes beyond organizational "fit", 58 and also beyond a financialstatement view of enterprise strength, to emphasize recognition of the most promising opportunities and the managerial orchestration needed to create, accommodate, and fashion resources both inside and outside the firm, at home and abroad. Included are the external linkages and alliances that are common in the global economy, and well documented and analyzed in the international business literature.

At a quite general level, dynamic capabilities are about how an enterprise seizes the future and develops the products, processes, and business models to meet (and shape) ever-changing markets. Dynamic capabilities result from superior top management orchestration skills. They are hard to teach, in part because there is a large tacit component (Teece et al., 1997).

The greater the diversity and rate of change in business environments, and the greater the importance of intangible (including relationship) assets, the more critical good strategy and strong dynamic capabilities become for the MNE's growth and financial performance. To maintain competitiveness, the MNE must develop and maintain asset alignment both internally and with collaborating firms. The MNE and its partner firms must develop and deliver joint "solutions" that are in tune with customer needs in multiple environments. It is not just a matter of selecting the right organizational boundaries to achieve fit, although that is clearly one element. ${ }^{59}$ Strong dynamic capabilities include the processes, business models, and leadership skills needed to effectuate high-performance sensing, seizing, and transforming. Strong dynamic capabilities help ensure evolutionary fitness; ordinary capabilities are more attuned to the requirements for technical fitness. ${ }^{60}$

\section{THE CAPABILITIES APPROACH JUXTAPOSED AGAINST TRADITIONAL MNE THEORY}

Prior sections of this paper have treated the firm in a general way, consistent with the need to encompass multinationality. This section explores particular issues squarely within the established domain of international business studies. It is, after all, the potential for synergistic interaction between headquarters and foreign locations (Cantwell, 2009), with their distinct institutional contexts and capabilities profiles, that distinguishes the MNE case from the general theory of the firm. Efforts are made to explain how a capabilities approach leads to an 
all-encompassing perspective that can incorporate both prongs of the internalization paradigm.

\section{Leveraging Capabilities Through Horizontal Expansion}

The specification of market-entry strategies is a key attribute of various internalization/governance theories of the MNE. One way to observe the different insights from the two main approaches to internalization is to examine how they impact perspectives on MNE expansion.

The impact of the transaction-cost-based internalization approach is already evident in the literature on the MNE (e.g., Hennart, 2009; Zahra et al., 2000). However, this stream of work tells us very little about which markets the MNE should create and enter; implicitly, one can perhaps read into internalization that the right markets are those in which the services of firm-specific assets generate value. In other words, transaction-cost-based internalization theories help specify entry mode, but not the best direction and timing for expansion. These are important decisions, and a robust theory of the MNE should be able to help explain them.

Clearly horizontal market-entry strategies of the MNE are not just about figuring out the right contractual mode. Firm-specific capabilities will need to be assessed, both as to relevance abroad and as to transfer costs. Modifications and adaptations may sometimes be required. Intellectual property issues will need to be analyzed. Replication of capabilities in a different context may be difficult (Teece, 1976, 1977a). In the main, the problems likely to be encountered are not contractual ones; they relate more to technology (and capability) transfer costs, and the assessment of market opportunity.

In effectuating such transfers, it is important for the MNE to minimize the "liability of foreignness" (Hymer, 1976; Zaheer, 1995) while simultaneously exploiting home-country benefits. As Helfat and Lieberman note:

Established firms enter markets where they have pre-entry resources and capabilities that are similar to the resource requirements of the market of entry. The choice of geographic markets is most strongly influenced by specialized resources and capabilities, including knowledge of the local market and tacit technological skills. (Helfat \& Lieberman, 2002: 738$)^{61}$

Thus firm-level capabilities act simultaneously both as a constraint on and as an enabler of what firms can do with respect to foreign market entry. International expansion will be facilitated when the firm capabilities align with market needs abroad, and management in the parent or subsidiary can keep it that way. The unevenness in the global business and economic landscape navigated by MNEs creates opportunities to both transfer and deploy existing capabilities, and create new ones, thereby fueling cross-border expansion. ${ }^{62}$

Hence, while the boundaries of the MNE may be partially determined by transaction costs, in larger measure they are likely to be determined by capabilities and the need for, and difficulty associated with, replication and the associated transfer of technologies and capabilities. This aspect of the argument echoes the theory of technological accumulation outlined by Cantwell (1989, 1995, 1999). It also implies that MNEs will invest abroad to augment their existing capabilities, as their geographically dispersed networks facilitate the accumulation of technological assets over time.

Accordingly, the boundaries of the MNE can be seen as resulting from entrepreneurial management developing and assembling the particular constellation of specific assets that the firm's activities require in each location where it elects to operate. The MNE becomes the locus for creating and leveraging products and capabilities, and for capturing value from this process globally. ${ }^{63}$ In the language of economic theory, value is achieved not just by minimizing transaction costs but also by exploiting (through management actions) the implicit bid-ask spreads associated with the "transfer" of intangible assets.

The MNE's country of origin is a key contextual factor. Regional and national systems of innovation, for instance, shape firm experiences, knowledge, and capabilities. Moreover, good management is not uniformly distributed either. Entrepreneurial management is a scarce resource that is itself geographically concentrated. Hence, as Madhok and Osegowitsch (2000: 326) note: "Home country characteristics have a strong bearing on the evolution of the domestic industry and the international competitiveness of individual firms". Firms are in part products of the environments in which they were born; by going global, they can tap into regional and national systems of innovation outside the home country. The capabilities of the MNE stem in part from the diverse environments in which they operate and compete.

However, most country advantages may be open to all that choose to invest in a particular host country. Low-cost labor, for example, is generally fungible across all foreign entrants. Hence, as discussed below, country-specific advantages are not so compelling in the (dynamic) capabilities-based 
approach to competitive advantage. They may help explain entry, but they are at best one factor behind competitive advantage at the enterprise or business level. In short, the essence of the MNE is that "it accepts, adapts to, and capitalizes on institutional, cultural, and market heterogeneity while simultaneously trying to capture economies associated with some kind of (scalable) advantage in certain assets or processes it owns or is currently developing" (Teece, 2006a: 125).

\section{How and When Do MNEs Enter New Geographic Markets?}

The mode of entry into a foreign market is the topic on which internalization theories have been thought to have their firmest footing. However, as discussed above, one cannot fully understand choices with respect to global expansion mode by looking at transaction cost/governance issues alone. At least two other factors are at work. First, the presence of pre-entry capabilities, including slack resources, matters considerably. An MNE will (and should) be reluctant to enter a foreign market (or even a proximate domestic market) if it doesn't have (or cannot readily access) at least strong ordinary capabilities and enough slack to replicate them without hitting internal resource constraints. The slack resources at issue might even be financial. Indeed, in Teece (1986b: 296), cash was highlighted as an important factor in explaining the mode of market entry. As Madhok (1997) notes, the firm boundary issues are largely capability-related. When a firm has strong ordinary and dynamic capabilities, the incremental costs of FDI are likely to be low.

Conversely, when timing is of the essence and certain capabilities are absent, joint ventures are likely to be preferred by the enterprise endeavoring to go global. When an MNE enters a foreign market, it will need to replicate some of the capabilities (processes, skills, etc.) employed in the home market. Adjustments may be necessary because the skills and knowhow the MNE possesses in one context might not quite work in a different geographic context. Getting this fit right requires dynamic capabilities.

Time-cost tradeoffs have been analyzed and empirically estimated for technology transfer processes (Teece, 1977b, 1980, 1986b). If the time-cost tradeoff is too steep, managers should associate with (joint) venture partners who can help flatten them. ${ }^{64}$ Joint ventures and collaboration not only reduce financial outlays; they often also enhance the MNE's ability to access local capabilities. Thus mode of entry will depend not just on contractual factors but also on who owns and controls the required capabilities, the time it takes to transfer them, and the timing imperatives of market entry.

Scholars have begun to study why and how some firms internationalize very early in life (e.g., Rennie, 1993; Oviatt \& McDougall, 1994). The "born global" phenomenon is consistent with dynamic capabilities. Small companies can have strong dynamic capabilities, and may be able to access abroad the ordinary capabilities necessary to make their foreign market-entry strategies viable. Small entrepreneurial firms can quickly create and (with local partners) cocreate new markets abroad.

Recent evidence (Arregle, Miller, Hitt, \& Beamish, 2013) indicates that prior investment in a region made up of multiple countries impacts future decisions to invest in these countries: that is, capabilities can be redeployed within regions more readily than between them. This finding, which goes beyond previous country-level analyses, is consistent with capability transfer being easier with geographic proximity, and with institutional and language similarity. The finding is more consistent with capabilities theories than with transaction cost/contract theories, although the two approaches reinforce each other, because contracting is also easier when institutions are more alike.

Dynamic capabilities themselves (involving as they do sensing, seizing, and, ultimately, transforming) can in most cases be sequenced over time and across different geographic markets. It is more challenging if the firm has to perform all three simultaneously in each of its businesses, and in all of its markets. However, such simultaneity is sometimes required. ${ }^{65}$ For example, Yum! Brands (the owner of fast-food brands KFC, Taco Bell, and Pizza Hut) has simultaneously engaged in rapid expansion in China, and in retrenchment and transformation in one of its established markets, the United Kingdom.

\section{The Role of Headquarters and the Subsidiary in Dynamic Capabilities Theory}

The governance (transaction cost) theory of internalization has little to say about the role of headquarters and foreign subsidiaries. ${ }^{66}$ Capabilities perspectives, on the other hand, provide insights into the respective roles of headquarters and subsidiaries.

The headquarters function is where certain capabilities reside. The M-form (multidivisional form) of organization facilitates decomposition of the MNE's architecture by allowing considerable autonomy to regional/country and divisional managers. 
Headquarters can enhance the firm's capabilities by allowing and facilitating technology transfers among the divisions, and by encouraging and supporting the exploitation of complementarities. ${ }^{67}$

Top management at headquarters performs a most important global asset orchestration function in the dynamic capabilities framework. They allocate the financial resources needed for the MNE to create markets outside the home jurisdiction while leaving operational matters to lower levels of the organization. As Peter Buckley (2009) notes in his (recent) work on the "global factory", the management style that network configurations require is vastly different from conventional "command and control" methods. Indeed, he refers to headquarters as "a 'controlling intelligence' or orchestrator of activities" (233). In essence, Buckley is advancing a dynamic capabilities perspective on the MNE.

Subsidiaries nevertheless play a vital role in the firm's dynamic capabilities. They can generate knowhow and capabilities from their own histories that can be transferred to other business units at home or abroad. This tends to be neglected and/or overlooked in transaction cost approaches. It's a significant and vibrant component of the literature on international management (e.g., Birkinshaw, 2000).

In fact, it has been recognized (Bartlett \& Ghoshal, 1989) that the MNE need not be especially hierarchical; it may well need to behave more like a network. Subsidiaries can have considerable autonomy, simultaneously being integrated in a worldwide operation. New products and processes can be developed by the parent or a subsidiary then shared globally. This decentralized M-form MNE allows and encourages local knowledge creation and local discovery of opportunities, with subsequent orchestration activities applied by top management. Transaction cost approaches provide few insights into this distribution of activity. However, it is consistent with work by Rugman and Bennett (1982) on world product mandates, and with later research by Birkinshaw and Hood (1998) on how local initiatives by foreign subsidiaries help generate and leverage local capabilities onto the global stage, and strengthen the MNE's competitive advantage.

It is important to recognize that once an MNE creates a subsidiary that establishes its own networks and learning path, the subsidiary can accumulate specific assets and capabilities that can find useful application elsewhere. As a sizable literature has documented, subsidiaries can engage in "reverse" technology transfer to the parent that may well generate opportunities (e.g., Birkinshaw, 1997; Birkinshaw \&
Pedersen, 2008; Phene \& Almeida, 2008; Prahalad \& Doz, 1981). Rugman and Verbeke (1992, 2001, 2003) also recognized quite properly that firm-specific assets could arise anywhere in the MNE. This is consistent with a capabilities perspective.

In short, capabilities perspectives elevate the MNE's subsidiaries in that they can be seen to contribute to the competitive advantage of the MNE, as recognized by many, including Birkinshaw, Hood, and Young (2005). Learning and the development of signature processes and VRIN resources are seen to be subsidiary-specific. This distribution of activity provides the opportunity to recognize what Bartlett and Ghoshal (1989) called "the transnational solution", combining astute (country-specific) blends of adaptation, rationalization, and centralization.

\section{Global Distribution of R\&D and Innovative Ecosystems}

An entrepreneurial/managerial theory of the firm must also be able to explain asset augmentation (i.e., the creation of firm-specific assets), asset exploitation, extension, and renewal. In the dynamic capabilities framework, asset augmentation comes fundamentally from $\mathrm{R} \& \mathrm{D}$ and learning processes (e.g., learning by doing; learning by using), whether internal or from (and with) partners, and from applying the logic of the "profiting from technological innovation" paradigm (Teece 1986b, 2006b). It also requires recognizing that innovation necessitates collaboration with a panoply of partners in an ecosystem. Ongoing engagement with ecosystem partners can be seen as leading to the migration of the locus of value creation from the firm to the level of the business ecosystem. External sourcing and collaboration can, when done well, augment the firm's internal capabilities (Capron \& Mitchell, 2009; Chesbrough, 2003). However, it can also drain them if partners are laggards, and fail to contribute as agreed.

The transaction cost-based internalization theory by no means ignored the role of R\&D. Indeed, it is of central importance in Buckley and Casson (1976). However, the development of firm-specific technological assets through internal and external combinations - and hence through dynamic capabilities - has not been emphasized much in the transaction cost approach. ${ }^{68}$ The capability to innovate not only depends on the amount spent on $\mathrm{R} \& \mathrm{D}$; it also depends critically on how that is spent, both as to whether it is done in house or outsourced, and on how well it is managed. Once again, good management requires excellence with respect to the 
orchestration function described earlier. Here the orchestration is of technology both inside and external to the firm, both at home and abroad, and across different technological domains.

Early studies of $R \& D$ in the foreign subsidiaries of US-based MNEs showed that, in the 1970s, companies used R\&D not just to access offshore talent, but (and mainly) to adapt technologies and products for local markets (Mansfield, Romeo, \& Teece, 1979). This is still the case, but the degree to which US enterprises use subsidiaries to develop new products has undoubtedly increased. Indeed, Cantwell and Kosmopoulou (2002) see R\&D migrating to sites where local conditions are most conducive to technology creation. Location decisions have much to do with market access and tapping into talent, and less to do with transaction cost issues.

The "foreign" subsidiary can also play a role not only in technology creation, but also in capturing value from innovation generated in any part of the MNE. The foreign subsidiary can invest in co-specialized manufacturing assets, co-specialized distribution/ marketing assets, and/or co-specialized technologies. Ownership of such assets can play an important role in the MNE's ability to profit from innovation. This is a quite general result from the innovation literature (Teece 1986b, 2006b), but it seems especially applicable to the MNE. These issues have been expanded at length by Cantwell and Mudambi (2005). For the purpose of this paper, the main point is that the global distribution of $R \& D$ can be seen as a phenomenon that supports the creation of capabilities in different geographies: capabilities that perhaps then need to be integrated to produce new products, as in the case of the civilian aircraft industry. Governance (transaction cost) theory produces only limited insight into this phenomenon. Insights from the strategy and capabilities perspectives seem more pertinent.

\section{Location and "Country" Factors and MNE Theory} Rugman has built a theory of the MNE that postulates the need to recognize that MNE location decisions are impacted by country-specific and firm-specific factors. In the Rugman matrices, for example, labor-intensive manufacturing operations of MNEs will be drawn to low-wage environments.

The dynamic capabilities framework suggests, however, that, while country and regional factors may impact investment location decisions, they usually have little relevance to understanding how MNE competitive advantage is anchored. The simple reason is that country factors are often exploitable to a substantial degree both by domestic firms and by multiple MNEs. Unless a particular MNE has a privileged relationship with a nation-state, or a unique and difficult-to-replicate history there, country advantages are accessible by all MNE investors.

Hence country factors may explain why economic activity of relevance to an MNE is in a particular offshore location. Internalization theory will help determine whether that activity is best accessed via outsourcing or by FDI. However, country (and regional) factors available to incumbents and new entrants alike will have little to do with explaining firm-level competitive advantage, except inasmuch as they help explain the history of particular units of the MNE. This is a place where traditional MNE theory and the theory of competitive advantage part ways.

In short, country and regional factors can be foundational for MNE competitive advantage only when a particular MNE is able to access local advantages and avoid local disabilities in a way that others cannot (or fail to) copy. For example, learning or other knowledge development that takes place in distinct host-country environments might form the basis for signature processes and VRIN resources that could contribute to competitive advantage for the company as a whole, and these would still be difficult for rivals to replicate.

In the framework advanced here, MNE competitive advantage flows from MNE-specific factors. These include not only the firm's innovation, corporate culture, and management, but also the locationspecific history and resources related to the firm's unique global footprint. This is where national systems of innovation (Nelson, 1993) are relevant, and this is all the more important because sources of innovation are more globally dispersed than ever before. If a host-country national system (and the MNE's history) affords privileged access to the national system, or to the outcome of the innovation process, then individual MNE competitive advantage is possible.

\section{INTERNATIONAL BUSINESS AND INTERNATIONAL (STRATEGIC) MANAGEMENT} The field of international business has been considerably animated by the tools and perspective of transaction cost economics. It has provided useful insights into enterprise structure and scope, into alliance arrangements, and into governance more generally. It outlines best practice with respect to contract design (an ordinary, not a dynamic, capability).

Contractual issues are of interest to policymakers and managers alike. However, there are a multiplicity of issues - such as global product mandates 
and understanding individual firm performance where the transaction cost approach has provided parsimonious insight at best. International management scholars have, as a consequence, sometimes developed communities of their own within management academies rather than the international business academies. As a result, their work has not been well integrated into the international business literature. Moreover, it often lacks a good theoretical grounding. Ad hoc theorizing is common. International management desperately needs a theory to help amalgamate its many disparate threads.

Scholars wedded to governance-based or exchangebased approaches may wish to explain profits and the competitive advantage of particular firms by appealing to the raison d'etre of firms in general. This is not possible. A general theory of the MNE that does not recognize firm-level heterogeneity is of little utility to scholars and practitioners interested in diagnosing the prospects and plights of particular firms.

The MNE manager's job in neoclassical theory and in early internalization/governance approaches is quite minimal. It is merely to:

(1) set output levels in each market such that marginal revenue equals marginal cost, and select inputs by rotating a price line around a transformation curve; and

(2) determine firm boundaries by outsourcing until the marginal cost of performing activities internally is equal to the cost of outsourcing, and align contractual structures according to the transaction specificity of assets. ${ }^{69}$

There is little recognition in internalization/governance approaches of the importance of discovery, learning, adjustment, and other forms of capability building. Unspecified mechanisms also somehow create firm-specific assets somewhere.

In a robust theory of the MNE, the manager's role needs to be broader. The dynamic capabilities framework achieves this by imbuing management with both entrepreneurial and leadership functions.

Bartlett and Ghoshal define what they call "transnational corporations" that have traits not unlike successful firms that are dynamically competitive. Their transnational enterprises build assets and capabilities that are dispersed and interdependent; overseas operations provide local differentiation but are nevertheless integrated into worldwide operations. These enterprises manage innovation through co-development and global sharing (Bartlett \& Ghoshal, 2002: 75).
The "transnational" approach, like much of the rest of the literature in international management (e.g., Doz \& Kosonen, 2008, 2010; Wilson \& Doz, 2011), appears to apply an implicit theory of the MNE that is animated more by firm-specific capabilities, learning, and networks than by transaction cost or governance considerations. Asset orchestration and entrepreneurial cross-border market creation and co-creation are at the core. What's missing is the careful identification of foundations and assumptions. This paper has endeavored to show how the implicit tenets in international management theory can fit comfortably within a broader capabilities/entrepreneurship-based theory of the MNE that explains not only its nature, as per Ronald Coase, but also its competitive advantage and associated financial performance over time. The (dynamic) capabilities framework advanced here allows international business and international management research to coexist in harmony.

In contrast to contractual approaches, the capabilities approach has an important role for the entrepreneurial manager, not just in asset orchestration but also in creating new products and services. It endeavors to explain heterogeneity and the determinants of firm-level profitability, not just the existence of firms. Access to distinct resources, the development of signature processes, engagement in co-creation activity, and implementation of good strategy each play a role. These concepts have, to date, had at best an awkward and quite limited home in contractual/governance-based theories.

\section{CONCLUSION}

The thrust of this paper is that transaction-costbased or comparative-governance-based theories of the MNE are too narrow to capture a good deal of what is critical to the MNE and its financial performance. (The OLI model, which has evolved to embrace capabilities alongside internalization, goes some way toward filling the gap.) Yet governanceoriented theories of the MNE still do not ask enough of the right questions, and they "read out" of the theory of the MNE cross-firm heterogeneity and any significant role for entrepreneurs, managers, and leaders. Notwithstanding, there is still utility to the paradigm.

What makes MNEs distinctive is the fact that they each have separate histories, and they each span jurisdictions and territories where markets, factors of production, firms and technologies, and national and regional infrastructure are likely to be different. 
Where certain capabilities and markets are absent, they need to be created. In these environments, entrepreneurs and managers in parents and subsidiaries build signature processes, deploy distinct resources, and design good business models and strategies in pursuit of profits. The basic question to be answered by a robust theory of the MNE is not simply where to locate in order to minimize production and transaction costs, but where to locate to build or deploy signature processes and obtain market access while guarding intellectual property and leveraging the firm's existing VRIN resources into new business/market environments.

What makes the MNE conceptually "interesting", and a challenge to model and manage, is that it operates/sells in multiple environments. Its activities must be consonant with those various environments, and, importantly, these environments often need to be shaped, and markets need to be "created". Accordingly, an MNE's dynamic capabilities must be more amplified and leveraged than those of a firm with a less ambitious, purely domestic, focus.

Importantly, the transaction cost/market failures paradigm that has hitherto anchored internalization (and much international business research) often deflects attention from critical managerial issues, and creates artificial tensions with research in international management. In the MNE theory advanced here, management's task is not just to overcome contractual difficulties; it must also build and leverage distinctive resources, signature processes, and signature business models, and combine assets internally and externally, guided by a prescient strategy. The MNE's growth and survival is not just about adapting to market failures; it's also about creating and deploying VRIN resources and signature processes and distinct business models to enable excellence in meeting (or possibly even modifying) market demand in ways that are hard for competitors to imitate. This, in turn, may lead the MNE to engage in technology and capability transfer, and possibly even the strengthening of complementors and suppliers. ${ }^{70}$ Put differently, the building and leveraging (extending) of dynamic capabilities can animate FDI decisions. In contrast, what seems to animate the firm in the transaction cost/market failure paradigm is mitigating contractual hazards. Clearly this is not sufficient to explain MNE activity, much less MNE heterogeneity.

Over the past 30 years, the international business literature has had a strong contractual/transaction cost flavor that has served it well. All along, there have been various strands that have toyed with capability ideas, but the international business literature has embraced issues of entrepreneurship and capabilities in only a limited fashion. Certainly there has been a gradual migration under way by some leading scholars of the contractual/exchange approach toward an implicit or explicit capabilities approach. However, when one slides from one paradigm to another in a subtle, undeclared way without announcement of old assumptions abandoned and new ones embraced, the literature runs the risk of becoming confused. Hence there is a need to be clear around the shifts that are going on, or progress will stall. Two of the goals of this paper have been to declare the tension, and to try to resolve it.

The multidisciplinary framework presented here advances capabilities concepts without ignoring governance/contractual issues. As international business scholars begin to more fully embrace the entrepreneurship/capabilities approach, a more unified theory of the MNE can emerge that will support a revamped internalization school, allowing a more productive dialogue among management scholars and practitioners. A more active interchange of research with strategy and management scholars as well as with researchers in (evolutionary) economics, organizations, and entrepreneurship - should follow. A richer internalization theory of the MNE will also allow management scholars as well as economists to talk meaningfully about the sources and persistence (or lack thereof) of firm-level competitive advantage and associated superior financial performance. With these developments, there is a good chance that the field of international business will escape its current confusion, and lead the way in advancing a parsimonious, tractable, and plausible theory of the firm and competitive advantage that will inform research, teaching, policy, and prescription across multiple fields of inquiry.

\section{ACKNOWLEDGEMENTS}

This paper is based in part on a presentation made at the Academy of International Business 2011 Annual Meeting, Nagoya, Japan, on 26 June 2011. Ideas based on a revised version were presented at the Academy of International Business 2013 Annual Meeting in Istanbul, Turkey, on 4 July 2013. I wish to thank Peter Buckley, John Cantwell, Jay Connor, Pankaj Ghemawat, Jean-Francois Hennart, Richard Nelson, Christos Pitelis, Alan Rugman, Stephen Tallman, Alain Verbeke, three anonymous reviewers, and especially Greg Linden and Sunyoung Leih for helpful comments and assistance. 


\section{NOTES}

${ }^{1}$ As Ronald Coase (1991) pointed out, it is not enough for a theory of the firm to merely explain firm boundaries. In particular, an acceptable theory of the firm needs to explain its "essence". Such a theory has yet to fully emerge, either in the domestic or in the MNE context. One might also hope that the theory could explain recent developments, such as greater outsourcing, greater geographical dispersion of R\&D activity, and the increase in international new ventures.

${ }^{2}$ This is obviously a more ambitious goal than most economists ever set themselves. See Hart (2011) for more discussion.

${ }^{3}$ Barreto (2010: 258) notes that "the dynamic capabilities view has attracted substantial attention from scholars publishing in top tier journals."

4"Entrepreneurship was a persistent, but seldom central, theme in these studies. In her early study of the internationalization of American Radiator Company, Mira Wilkins criticized the insufficiency of international business theories based purely on comparative advantage and strategic thinking, and highlighted the importance of evolutionary choices and uncertainty in entrepreneurial decision-making. She emphasized the importance of understanding a series of specific pathdependent entrepreneurial decisions in the firm's growth that shaped options and outcomes... Wilkins also discussed the 'alert American entrepreneurs' who 'sought opportunities beyond the national boundaries' (Jones and Wadhwani, 2007: 6).

${ }^{5}$ As Paul Walker notes, "expanding the orthodox view of the firm to include the new reality of the knowledge economy should be an urgent issue on the economic research agenda" (Walker, 2009: 29).

${ }^{6}$ Peter Buckley likewise notes that "transaction costs are, of course, not the whole story (again) but they are an indispensable part of the whole story" (Buckley, 2009: 227).

${ }^{7}$ The goal here is not only to explain the nature of firms and their scope as per Coase (1937); it is also to explain profit as per Knight (1921), although Knight's interest in profits was primarily at the economy-wide level, less so at the firm level.

${ }^{8}$ Williamson (1999) seems to agree that an unaddressed issue in this literature is the generation of differential firm performance.

${ }^{9}$ Hymer confused competitive advantage and monopoly power. Competitive advantage need not, and usually does not, imply that the firm possesses any policy-relevant market power.

${ }^{10}$ Oliver Williamson (1985) sometimes chooses to call transaction cost economics the "governance" approach, as the framework endeavors to explain how transactions are organized or "governed".

${ }^{11}$ Writing within this first prong, the Coasian paradigm, Teece (1976: 104) also noted that "technology transfer can be facilitated within the multinational firm because of economies realized with respect to transactions costs, and the superior incentive and control devices that the firm possesses and has available for use".

${ }^{12}$ Governance structures are arrangements by which a transaction can be managed (governed) to mitigate potential market exchange problems. Governance structures encompass: (1) incentive intensity; (2) form of administrative control; and (3) contract law regime (Williamson, 1991).

${ }^{13}$ None of the textbook models of the firm - whether generic or MNE oriented - captures the changes to the MNE that movement toward a (global) knowledge economy seems to entail. As Oliver Hart has recognized, "most formal models of the firm are extremely rudimentary, capable only of portraying hypothetical firms that bear little relation to the complex organizations we see in the world" (Hart, 1989: 1757).

${ }^{14}$ Ownership advantages were not entirely firmspecific in Dunning's treatment. However, Rugman (1981) interpreted O advantages primarily as firmspecific advantages (FSAs) - that is, specific to individual firms. I owe thanks to Cantwell for valuable comments on this point.

${ }^{15}$ The literature is still unsettled with respect to whether ownership advantages are endogenous or exogenous (Cantwell \& Narula, 2003). Scholars have noted that changes in the value of both exogenous and endogenous variables affect each other. Dunning, for instance, explains that assetseeking FDI at time $t$ may well affect $L$ advantages of the host country in time $t+1$, and the choice of $L$ affects their future $O$ advantages, which requires "a reconfiguration of traditional OLI variables" (Dunning, 2001: 178).

${ }^{16}$ As learning takes place in multiple organizational and geographic sites, and with different complementarities, different performance levels are achieved by different businesses. Different learning processes enable particular firms to stay on different paths and achieve peaks on today's rugged and very global industrial landscape. Moreover, idiosyncratic pathdependent learning follows management's initiation of action, the establishment of routines, and the development of organizational memory. This produces "rugged landscapes" (Levinthal, 1997: 934). Furthermore, the industrial landscape quite simply isn't flat, either domestically or abroad. Heterogeneity is the 
norm, and is explained in part by the existence of pathdependent learning.

${ }^{17}$ The distinction being made here is a specific instance of the general difference between "formal" and "appreciative" theorizing (Nelson \& Winter, 1982). The former is a precise approach based on abstract models that attempt to reveal something meaningful about the real world despite their simplifications. Appreciative theorizing is qualitative, and takes observations of the real world as its starting point.

${ }^{18}$ The task at hand for managers is bigger than simplifying transactional difficulties by engaging in direct investment in wholly owned subsidiaries. Early path-breaking ideas, such as copiers or scanners, are often met with skepticism and over-pessimistic guesstimates of their market potential. In such cases, it is left to the originators of these ideas to try to prove themselves right. This has often required amassing the co-specialized and complementary assets needed to set up an organization and adopt the requisite structures and strategies to create or co-create new markets (Pitelis \& Teece, 2010) and reveal new sources of demand.

${ }^{19} \mathrm{I}$ also noted in my very early work that "the literature on the multinational enterprise, whether emphasizing market power or efficiency, suffers from a common deficiency: underemphasis on dynamics" (Teece, 1986a: 36); and that "transaction cost economics must be married to organizational decision theory if the dynamics of channel selection are to be better understood" (Teece, 1986a: 37). Market creation and co-creation are of course dynamic processes. In the above quote, organizational decision theory is a poorly worded proxy for what I now call dynamic capabilities theory, discussed below.

${ }^{20} \mathrm{~A}$ look at the cross-border activities of global firms is in line with our arguments. Take, for example, a firm such as Coca-Cola, and its cross-border activities in China and India. These do not simply involve activities that are tantamount to solving existing market failures. Instead, they involve the transfer of capabilities and the creation of markets by designing and setting up bottling companies and distribution systems; by inventing new refrigerating technology; and by influencing user perceptions.

${ }^{21}$ There is little room for uncertainty or innovation in the various Coasian models of the MNE, and extensions have not succeeded in creating theories that incorporate learning, capability enhancement, and innovation in a meaningful way.

${ }^{22}$ Williamson recognizes Koopmans' (1957) distinctions between primary and secondary uncertainty - but uncertainty implicates transaction cost economics only through its impact on the contracting process. Like Coase, Williamson does not recognize Knightian, or fundamental, uncertainty.

${ }^{23}$ Buckley has recently recognized that "the links between the (multinational) firm, entrepreneurship and transaction costs are strong" (Buckley, 2009: 227). However, his treatment of entrepreneurship is mainly contractual.

${ }^{24}$ The econometric results in Monteverde and Teece (1982) showed that vertical integration was driven not just by asset specificity. "Systems effects" and firm-level effects were empirically much larger. In particular, there are a variety of contractual arrangements, some more firm-like, some more market-like.

${ }^{25}$ There is considerable sentiment that transaction cost approaches to vertical integration and MNE expansion (through wholly owned subsidiaries) put too much emphasis on "hold-up" and recontracting hazards. For example, General Motors' acquisition of Fisher Body, which has been used as the canonical example of hold-up, has been shown on closer examination to reflect just the opposite (i.e., GM management trusted the Fisher Brothers, which is the reason they bought the company) (Chandler \& Salsbury, 1971; Goldberg, 2008).

${ }^{26}$ Dunning, with his OLI approach, made a step in the right direction; but OLI is also mostly static, and fails to recognize capability building or entrepreneurial and learning considerations (Pitelis, 2007). Rugman and Verbeke (1992, 2001) incorporate strategic management thinking into the internalization theory using the concepts of "location-bound" and "non-locationbound".

${ }^{27}$ Interestingly, Casson has written extensively and with considerable insight on entrepreneurship, aiming to integrate entrepreneurial decision-making into the theory of the firm. Using a definition arising from information cost economics, Casson (2005: 325) views judgmental decision-making as the defining characteristic of the entrepreneur, which requires the entrepreneur to develop skills for optimizing information selection and processing. Although Casson endeavored to incorporate the entrepreneur into the theory of the firm, his theory does not seem to fully capture the entrepreneurial function of the MNE manager as advanced here. A key reason is that organizational knowledge and capabilities are distinct from the summation of the individuals' knowledge and skills, and Casson's approach seems to be focused more on the latter. Also, they often remain tacit (Polanyi, 1958).

${ }^{28}$ In today's global economy, there is considerable standardization of products and certain manufacturing 
technologies, and markets are more open than they used to be. However, homogenization of tasks and technologies has not yet occurred, and is unlikely to do so any time soon. Differences in consumer preferences and purchasing power also remain, and will likely continue to do so.

29"When it comes to the international expansion of manufacturing production itself a pure theory of exchange is on weaker ground... [Technology] may accumulate within the firm not so much because of the characteristics of the market for technology once it has been created, as because of the conditions under which it is most easily generated and used in production" (Cantwell, 1989: 216).

${ }^{30}$ In Dunning's eclectic paradigm, and in Teece (1986b), competitive advantage flows from the ownership of particular unique intangible assets (such as firm-specific technology), and from the ownership of certain complementary assets.

${ }^{31}$ As Machiavelli noted in The Prince 500 years ago: "The prince who relies entirely on fortune is lost when it changes... he whose actions do not accord with the times will not be successful... if times and affairs change, he is ruined if he does not change his course of action".

${ }^{32}$ Note that the "positioning" referenced here is not market positioning, in the manner used by Porter (1980). Market share is of little relevance to this analysis, except when there are strong network effects. The external business environment - writ large - is, however, highly relevant. This is perhaps better summarized by the concept of the ecosystem rather than industry (Teece, 2012).

${ }^{33}$ The approach does not deny that firms are necessary to delimit recontracting hazards and other negative consequences of opportunism. Rather, the theory goes beyond this to recognize the need to organize so as to embrace opportunity, and to capture gains from discovering and exploiting scope economies derived from complementarities and co-specialization.

${ }^{34}$ An observation variously attributed to Charles de Gaulle and Lou Gerstner holds that "You have to be fast on your feet and adaptive, or else a strategy is useless". Whoever originally said this, it makes an important point: a good strategy must be combined with strong dynamic capabilities to be effective.

${ }^{35}$ According to Rumelt (2011: 7), a guiding policy specifies the approach to dealing with the obstacles called out in the diagnosis. Coherent actions are feasible, coordinated actions diagnosed to carry out the guiding policy.

${ }^{36}$ For presentational purposes, strategy can be viewed as embedded in dynamic capabilities. They are interdependent. In many cases, however, it is helpful for strategy to be analytically separated. This is the approach followed in the remainder of this paper.

${ }^{37}$ McDonald's is an excellent example of a firm that has grown globally based on an ability to replicate and manage assets in multiple jurisdictions.

${ }^{38}$ Ordinary in the sense of maintaining the status quo (that is, not out of the ordinary) (Helfat \& Winter, 2011: 1244).

${ }^{39}$ For instance, the most proficient manufacturer of vacuum tubes with bountiful ordinary capabilities was defeated, as were others in the vacuum tube industry, by the invention and mass production of transistors. However, in markets that are protected from competition - possibly because of government regulations or trade barriers, or which are small-scale - ordinary capabilities may allow a company to be profitable and grow reasonably well.

${ }^{40}$ Dynamic capabilities are generally required for the transfer and adaptation of ordinary capabilities on a global scale. However, when global markets are relatively homogeneous, such scaling may not require significant adaptation. The mere transfer of technologies (without adaptation) to different geographies represents the extension of ordinary capabilities - one step short of dynamic capabilities.

${ }^{41}$ Technical fitness is defined by how effectively a capability performs its function, regardless of how well the capability enables a firm to make a living (Teece, 2007: 1321).

${ }^{42}$ Of course, in many poor countries with extensive state control of resources, competitive forces are weak, and firms with ordinary capabilities can survive and prosper if ordinary capabilities are rare.

${ }^{43}$ Benchmarkers often study "best of breed" or peerless performers of particular functions (e.g., what can the shipping department learn from Federal Express?).

${ }^{44}$ Bloom et al. (2012) identified 18 management practice domains. These seem to represent particular ordinary capabilities, as discussed below.

${ }^{45}$ The fast-food industry is another example, although capabilities are perhaps not yet as complete on a global basis.

${ }^{46}$ Nelson dates this development from the mid1970s.

${ }^{47}$ Cloud computing enables "ubiquitous, convenient, on-demand network access to a shared pool of configurable computing resources (e.g., networks, servers, storage, applications, and services) that can be rapidly provisioned and released with minimal management effort or service provider interactions" (Mell \& Grance, 2011). These resources can be provisioned 
to small businesses or across large multinational corporations.

${ }^{48}$ Unpublished comments made at the Academy of International Business meeting, Nagoya, Japan, 26 June 2011.

${ }^{49}$ Bloom and Van Reenen (2010) explored reasons why ordinary capabilities were less prevalent in developing countries. Their large-scale, cross-country survey results suggested that an information gap was perhaps the biggest contributor; managers were generally not well-informed about how their own practices compared to best practices. Specific conditions that could also lead to poor management practices in developing countries include weak product market competition, state ownership, family-based management, and poor business education.

${ }^{50}$ Intellectual capital, in particular, is generally harder to develop, transfer, and imitate (Teece, 2000).

${ }^{51}$ Evolutionary fitness refers to how well the capability enables a firm to make a living (Teece, 2009: 7). Dynamic capabilities allow an organization to change in a manner that supports evolutionary fitness. They govern how new products and services are developed and positioned, how new business models are created, and how ordinary capabilities improve.

${ }^{52}$ For instance, an important function in drug development is achieving regulatory approval. At present, many major pharmaceutical companies have well-developed processes (for running the approval process). In time, however, such processes could become standardized, and available from a business service provider. When this occurs, a higher-order capability in the pharmaceutical industry will become a lower-order (ordinary) capability.

${ }^{53}$ There may be multiple niches available to a firm for surviving, given the environment. The higher the environmental complexity that can be handled by the firm, the better the long-run performance.

${ }^{54}$ Winter (2003) approaches dynamic capabilities as being rooted in higher-level change routines. The core of a capability is patterned activity oriented to relatively specific objectives (p. 992). He differentiates dynamic capabilities from ad hoc problem-solving, and views a dynamic capability as a skill or routine that must be maintained (p. 994).

${ }^{55}$ Discovering and exploiting discrepancies in factor prices across jurisdictions is an element of the entrepreneurial function of the MNE.

${ }^{56}$ Drnevich and Kriauciunas (2011: 275) found that firms may achieve higher relative performance by increasing ordinary capability usage in stable environments and increasing dynamic capability usage in dynamic environments.
${ }^{57}$ Many discussions of operations strategy drift into what I think of as dynamic capabilities. Some scholars see operations strategy as developing resources and configuring processes so that there is good strategic fit with the business environment (Van Mieghem, 2008: 18). In the fast-food industry, for example, ordinary capabilities involve key performance indicator metrics, training systems, motivation, monitoring, and so on. Dynamic capabilities address figuring out new product to put on the menu, new operating hours (e.g., late night), and new locations (central vs suburban). These are critical decisions in the MNE context.

${ }^{58}$ Simon (1969) defines three modes of coping with the environment: passive insulation, reactive negative feedback, and predictive adaptation. Miles and Snow (1978) also lay out a taxonomy with respect to how firms can adapt.

${ }^{59}$ Building organizations that possess and appropriately exercise dynamic capabilities isn't at all easy. It's not simply about standardization, rationalization, or centralization; these are more associated with ordinary capabilities than with dynamic capabilities. In the global context, dynamic capabilities involve being sensitive to local markets and national systems of innovation, while also achieving integration across markets where scale allows and requires it.

${ }^{60}$ Fitness is somewhat akin to contingency theory, and the alignment of organizational design with context (Burns \& Stalker, 1961).

${ }^{61}$ This is somewhat consistent with the revised thinking of Hennart (2009).

${ }^{62}$ As Rugman and Verbeke (1993: 74-75) note, "a substantial body of literature exists which suggests that large MNEs are becoming increasingly independent from individual countries; they use selective parts of national diamonds to gain global advantages. In each of these cases, an MNE's core competence is considered to be its ability to coordinate and control operations which are globally dispersed as a result of a wide variety of location advantages associated with industrial nations or regions".

${ }^{63}$ Of course, the advantages of complex coordination being conducted inside the firm are featured in many theories of the firm (e.g., Barnard, 1938; Hennart, 1977, 1982). However, the type of "coordination" discussed here - coordination that involves orchestrating co-specialized complements and intellectual property - is rather different from what has been featured before.

${ }^{64}$ Dierickx and Cool (1989) do not use the language of time-cost tradeoffs; they speak of "time compression diseconomies" (p. 1504). They appear to be getting at the same idea. 
${ }^{65}$ As O'Reilly, Harreld, and Tushman (2009) note, this is not only required, it is sometimes achieved.

${ }^{66}$ This is despite the fact that Oliver Williamson, one of the pioneers of transaction cost thinking, wrote a good deal about the M-form structure (e.g., Williamson, 1975).

${ }^{67}$ Headquarters management can perform an important set of functions by promoting and protecting organizational learning, co-specialized technology transfer, and capability accumulation. Entrepreneurial leadership can come from the parent or the subsidiaries.

${ }^{68}$ The exception here is Chesbrough and Teece (1996). However, this treatment gave insufficient weight to capabilities.

${ }^{69}$ This formulation is based on Coase (1937). Williamson (1985) frames the boundary choice issue as one of minimizing both what he calls "governance"

\section{REFERENCES}

AFP. 2013. Apple reiterates its ability to "create magic". Taipei Times, 14 February. http://www.taipeitimes.com/News/ biz/archives/2013/02/14/2003554839, accessed 15 February 2013.

Argote, L., \& Ingram, P. 2000. Knowledge transfer: A basis for competitive advantage in firms. Organizational Behavior and Human Decision Processes, 82(1): 150-169.

Arregle, J. -L., Miller, T. L., Hitt, M. A., \& Beamish, P. W. 2013. Do regions matter? An integrated institutional and semiglobalization perspective on the internationalization of MNEs. Strategic Management Journal, 34(8): 910-934.

Augier, M., \& Teece, D. I. 2007. Dynamic capabilities and multinational enterprise: Penrosean insights and omissions. Management International Review, 47(2): 175-192.

Augier, M., \& Teece, D. J. 2008. Strategy as evolution with design: The foundations of dynamic capabilities and the role of the managers in the economic system. Organizational Studies, 29(8-9): 1187-1208.

Barnard, C. I. 1938. The functions of the executive. Cambridge, MA: Harvard University Press.

Barney, J. B. 1986. Organizational culture: Can it be a source of sustained competitive advantage? Academy of Management Review, 11(3): 656-665.

Barney, J. B. 1991. Firm resources and sustained competitive advantage. Journal of Management, 17(1): 99-120.

Barreto, I. 2010. Dynamic capabilities: A review of past research and an agenda for the future. Journal of Management, 36(1): 256-280.

Bartlett, C. A., \& Ghoshal, S. 1989. Managing across borders: The transnational solution. Boston, MA: Harvard Business School Press.

Bartlett, C. A., \& Ghoshal, S. 2002. Managing across borders: The transnational solution, 2nd edn. Cambridge, MA: Harvard Business School Press.

Birkinshaw, J. 1997. Entrepreneurship in multinational corporations: The characteristics of subsidiary initiatives. Strategic Management Journal, 18(3): 207-229.

Birkinshaw, J. 2000. Entrepreneurship in the global firm. London: SAGE.

Birkinshaw, J., \& Hood, N. 1998. Multinational subsidiary evolution: Capability and charter change in foreign-owned subsidiary companies. Academy of Management Review, 23(4): 773-795.

Birkinshaw, J., Hood, N., \& Young, S. 2005. Subsidiary entrepreneurship, internal and external competitive forces, and costs and "production" costs. Governance costs depend importantly on whether the task at hand requires investment in idiosyncratic (transaction-specific) assets.

${ }^{70}$ The Boeing 787 Dreamliner case is relevant here as a counter-example. In designing a supply chain for its new 787 Dreamliner passenger jet, Boeing decided to rely far more than ever before on a global array of suppliers to develop parts and subsystems. Unfortunately, it also cut back its monitoring capability, without having first ensured that all suppliers had the requisite design and production capabilities. Problems with inadequate components led to a delay of more than three years (Kesmodel, 2011). The problems were not, at heart, contractual ones; they arose more from capability deficiencies than from opportunism.

subsidiary performance. International Business Review, 14(2): 227-248.

Birkinshaw, J., \& Pedersen, T. 2008. Strategy and management in MNE subsidiaries. In A. M. Rugman (Ed), Oxford handbook of international business, 2nd edn: 367-388. Oxford: Oxford University Press.

Bloom, N., \& Van Reenen, J. 2010. Why do management practices differ across firms and countries? Journal of Economic Perspectives, 24(1): 203-224.

Bloom, N., Genakos, C., Sadun, R., \& Van Reenen, J. 2012. Management practices across firms and countries. Academy of Management Perspectives, 20(1): 12-33.

Brouthers, K. 2013. A retrospective on: Institutional, cultural and transaction cost influences on entry mode choice and performance. Journal of International Business Studies, 44(1): 14-22.

Buckley, P. I. 2007. The strategy of multinational enterprises in the light of the rise of China. Scandinavian Journal of Management, 23(2): 107-126.

Buckley, P. J. 2009. Internalisation thinking: From the multinational enterprise to the global factory. International Business Review, 18(3): 224-235.

Buckley, P. J. Forthcoming. Buckley and Casson. In M. Augier, \& D. J. Teece (Eds), Encyclopedia of strategic management. Basingstoke: Palgrave Macmillan.

Buckley, P. J., \& Casson, M. C. 1976. The future of the multinational enterprise. London: Palgrave Macmillan.

Buckley, P. J., \& Casson, M. C. 1998. Analyzing foreign market entry strategies: Extending the internalization approach. Journal of International Business Studies, 29(3): 539-561.

Burns, T., \& Stalker, G. M. 1961. The management of innovation. London: Tavistock.

Cantwell, I. A. 1989. Technological innovation and multinational corporations. Oxford: Blackwell.

Cantwell, I. A. 1995. The globalization of technology: What remains of the product cycle model? Cambridge Journal of Economics, 19(1): 155-174.

Cantwell, J. A. 1999. From the early internalization of corporate technology to global technology sourcing. Transnational Corporations, 8(2): 71-92.

Cantwell, J. A. 2009. Location and the multinational enterprise. lournal of International Business Studies, 40(1): 35-41.

Cantwell, J., Dunning, J. H., \& Lundan, S. M. 2010. An evolutionary approach to understanding international business activity: The co-evolution of MNEs and the institutional environment. Journal of International Business Studies, 41(4): 567-586. 
Cantwell, J. A., \& Kosmopoulou, E. 2002. What determines the internationalization of corporate technology? In V. Havila, M. Forsgren, \& H. Hakanson (Eds), Critical perspectives on internationalization: 305-334. Oxford: Pergamon.

Cantwell, J. A., \& Mudambi, R. 2005. MNE competence-creating subsidiary mandates. Strategic Management Journal, 26(12): 1109-1128.

Cantwell, J., \& Narula, R. 2003. Revisiting the eclectic paradigm. In J. Cantwell, \& R. Narula (Eds), International business and the eclectic paradigm: 1-20. London: Routledge.

Capron, L., \& Mitchell, W. 2009. Selection capability: How capability gaps and internal social frictions affect internal and external strategic renewal. Organization Science, 20(2): 294-312.

Casson, M. C. 1979. Alternatives to the multinational enterprise. London: Palgrave Macmillan.

Casson, M. C. 1982. The entrepreneur: An economic theory. Oxford: Martin Robertson.

Casson, M. C. 1986a. Contractual arrangements for technology transfer: New evidence from business history. Business History, 28(4): 5-35.

Casson, M. C. 1986b. General theories of the multinational enterprise: Their relevance to business history. In P. Hertner, \& G. Jones (Eds), Multinationals: Theory and history: 42-68. Aldershot: Gower.

Casson, M. C. 1997. Information and organization: A new perspective on the theory of the firm. Oxford: Clarendon Press.

Casson, M. C. 2000. Enterprise and leadership: Studies on firms, networks and institutions. Cheltenham: Edward Elgar.

Casson, M. C. 2005. Entrepreneurship and the theory of the firm. Journal of Economic Behaviour and Organization, 58(2): 327-348.

Chandler, A. 1977. The visible hand. Cambridge, MA: The Belknap Press of Harvard University Press.

Chandler, A., \& Salsbury, S. 1971. Pierre S. Du Pont and the making of the modern corporation. New York: Harper \& Row.

Chesbrough, H. 2003. Open innovation: The new imperative for creating and profiting from technology. Boston, MA: Harvard Business School Press.

Chesbrough, H., \& Teece, D. J. 1996. When is virtual virtuous? Organizing for innovation. Harvard Business Review, 74(1): 65-73.

Coase, R. 1937. The nature of the firm. Economica, 4(16): 386-405.

Coase, R. 1991. The nature of the firm: Influence. In O. Williamson, $\&$ S. Winter (Eds), The nature of the firm: Origins, evolution and development: 61-74. Oxford: Oxford University Press.

Dierickx, I., \& Cool, K. 1989. Asset stock accumulation and sustainability of competitive advantage. Management Science, 35(12): 1504-1511.

Doz, Y., \& Kosonen, M. 2008. The dynamics of strategic agility: Nokia's rollercoaster experience. California Management Review, 50(3): 95-118.

Doz, Y., \& Kosonen, M. 2010. Embedding strategic agility: A leadership agenda for accelerating business model renewal. Long Range Planning, 43(2): 370-382.

Drnevich, P. L., \& Kriauciunas, A. P. 2011. Clarifying the conditions and limits of the contributions of ordinary and dynamic capabilities to relative firm performance. Strategic Management Journal, 32(3): 254-279.

Dunning, J. H. 1981. Alternative channels and modes of international resource transmission. In R. W. Moxon, \& H. V. Perlmutter (Eds), Controlling international technology transfer: Issues, perspectives and implications: 3-27. New York: Pergamon Press.

Dunning, J. H. 1995. Reappraising the eclectic paradigm in the age of alliance capitalism. Journal of International Business Studies, 26(3): 461-493.

Dunning, J. H. 2001. The eclectic (OLI) paradigm of international production: Past, present and future. International Journal of the Economics of Business, 8(2): 173-190.

Dunning, J. H., \& Lundan, S. M. 2008. Multinational enterprises and the global economy. Cheltenham: Edward Elgar.

Dunning, J. H., \& Lundan, S. M. 2010. The institutional origins of dynamic capabilities in multinational enterprises. Industrial and Corporate Change, 19(4): 1225-1246.
Dunning, J., \& Pitelis, C. N. 2008. Stephen Hymer's contribution to international business scholarship: An assessment and extension. Journal of International Business Studies, 39(1): 167-176.

Eisenhardt, K., \& Martin, J. 2000. Dynamic capabilities: What are they? Strategic Management Journal, 21(10-11): 1105-1121.

Ernst, D., \& Guerrieri, P. 1998. International production networks and changing trade patterns in East Asia: The case of the electronics industry. Oxford Development Studies, 26(2): 191-212.

Gans, J., \& Stern, S. 2010. Is there a market for ideas? Industrial and Corporate Change, 19(3): 805-837.

Gereffi, G., Humphrey, I., \& Sturgeon, T. 2005. The governance of global value chains. Review of International Political Economy, 12(1): 78-104.

Ghemawat, P. 2003. Semiglobalization and international business strategy. Journal of International Business Studies, 34 (2): 138-152.

Goldberg, V. P. 2008. Lawyers asleep at the wheel? The GM-Fisher Body contract. Industrial and Corporate Change, 17(5): 1071-1084.

Gratton, L., \& Ghoshal, S. 2005. Beyond best practice. MIT Sloan Management Review, 46(3): 49-57.

Greiner, L. E. 1998. Evolution and revolution as organizations grow, 1972. Harvard Business Review, 76(3): 55-60, 62.

Hart, O. 1989. An economist's perspective on the theory of the firm. Columbia Law Review, 89(7): 1757-1774.

Hart, O. 2011. Thinking about the firm: A review of Daniel Spulber's "The Theory of the Firm". Journal of Economic Literature, 49(1): 101-113.

Helfat, C. E., \& Lieberman, M. B. 2002. The birth of capabilities: Market entry and the importance of pre-history. Industrial and Corporate Change, 11(4): 725-760.

Helfat, C. E., \& Winter, S. G. 2011. Untangling dynamic and operational capabilities: Strategy for the (n)everchanging world. Strategic Management Journal, 32(11): 1243-1250.

Helper, S., \& Sako, M. 2012. Management innovation in supply chain: Appreciating Chandler in the twenty-first century. In W. Lazonick, \& D. Teece (Eds), Management innovation: Essays in the spirit of Alfred D. Chandler, Jr.: 147-178. Oxford: Oxford University Press.

Hennart, J. F. 1977. A theory of multinational enterprise. PhD dissertation, University of Maryland, College Park, MD.

Hennart, J. F. 1982. A theory of multinational enterprise. Ann Arbor: University of Michigan Press.

Hennart, J. F. 2009. Down with MNE-centric theories! Market entry and expansion as the bundling of MNE and local assets. Journal of International Business Studies, 40(9): 1432-1454.

Hennart, J. F. 2010. Transaction cost theory and international business. Journal of Retailing, 86(3): 257-269.

Hymer, S. H. 1968. La grande "corporation" multinationale: Analyse de certaines raisons qui poussent à l'intégration international des affaires. Revue Economique, 14(6): 949-973.

Hymer, S. H. 1976. The international operations of national firms: A study of direct foreign investment. Cambridge, MA: MIT Press.

Jones, G. 2005. Multinationals and global capitalism: From the nineteenth to the twenty-first century. New York: Oxford University Press.

Jones, G., \& Wadhwani, R. D. 2007. Entrepreneurial theory and the history of globalization. Business and Economic History, 5. http://www.h-net.org/ business/bhcweb/publications/BEHonline/2007/joneswadhwani.pdf, accessed 1 August 2012.

Kesmodel, D. 2011. Boeing examines supply chain for weak links. WSI.com, 30 December. http://online.wsj.com/article/ SB10001424052970204058404577111091095438300.html, accessed 30 December 2011.

Kirkpatrick, D. 1998. The second coming of Apple: Through a magical fusion of man - Steve Jobs - and company, Apple is becoming itself again: the little anticompany that could, Fortune, 9 November. http://money.cnn.com/magazines/fortune/ 
fortune_archive/1998/11/09/250834/index.htm, accessed 8 August 2012.

Knight, F. 1921. Risk, uncertainty and profit. New York: Augustus Kelley.

Knott, A. 2003. The organizational routines factor market paradox. Strategic Management Journal, 24(10): 929-943.

Kogut, B., \& Zander, U. 1992. Knowledge of the firm: Combination, capabilities, and the replication of technology. Organizational Sciences, 3(3): 383-397.

Kogut, B., \& Zander, U. 1995. Knowledge, market failure and the multinational enterprise: A reply. Journal of International Business Studies, 26(2): 417-426.

Koopmans, T. C. 1957. Three essays on the state of economic science. New York: McGraw-Hill.

Langlois, R. N. 2007. The entrepreneurial theory of the firm and the theory of the entrepreneurial firm. Journal of Management Studies, 44(7): 1107-1124.

Levinthal, D. A. 1997. Adaptation on rugged landscapes. Management Science, 43(7): 934-950

Lippman, S. A., \& Rumelt, R. P. 1982. Uncertain imitability: An analysis of inter-firm differences in efficiency under competition. Bell Journal of Economics, 13(2): 418-438.

Lutz, B. 2011. Life lessons from the car guy. WSJ.com, 11 June. http://online.wsj.com/article/SB100014240527023042593 $04576375790237203556 . h t m l$, accessed 15 June 2011.

Madhok, A. 1997. Cost, value and foreign market entry mode: The transaction and the firm. Strategic Management Journal, 18(1): 39-62.

Madhok, A., \& Osegowitsch, T. 2000. The international biotechnology industry: A dynamic capabilities perspective. Journal of International Business Studies, 31(2): 325-335.

Mansfield, E., Romeo, A., \& Teece, D. 1979. Overseas research and development by US-based firms. Economica, 46(182): 187196.

Mell, P., \& Grance, T. 2011. The NIST definition of cloud computing. NIST Special Publication 800-145. Gaithersburg, MD: National Institute of Standards and Technology. http://csrc.nist .gov/publications/nistpubs/800-145/SP800-145.pdf, accessed 10 November 2012.

Miles, R. E., \& Snow, C. C. 1978. Organizational strategy, structure, and process. New York: McGraw-Hill.

Monteverde, K., \& Teece, D. J. 1982. Supplier switching costs and vertical integration in the automobile industry. The Bell Journal of Economics, 13(1): 206-213.

Nelson, R. R. (Ed) 1993. National systems of innovation. New York: Oxford University Press.

Nelson, R. R., \& Winter, S. G. 1982. An evolutionary theory of economic change. Cambridge, MA: Harvard University Press.

O'Reilly, C. A., Harreld, J. B., \& Tushman, M. L. 2009. Organizational ambidexterity: IBM and emerging business opportunities. California Management Review, 51(4): 75-99.

Oviatt, B. M., \& McDougall, P. P. 1994. Toward a theory of international new ventures. Journal of International Business Studies, 25(1): 45-64.

Penrose, E. T. 1959. The theory of the growth of the firm. New York: John Wiley.

Perlmutter, H. V. 1969. The tortuous evolution of the multinational corporation. Columbia Journal of World Business, 4(1): 9-18.

Phene, A., \& Almeida, P. 2008. Innovation in multinational subsidiaries: The role of knowledge assimilation and subsidiary capabilities. Journal of International Business Studies, 39(5): 901-919.

Pitelis, C. N. 2004. Edith Penrose and the resource-based view of (international) business strategy. International Business Review, 13(4): 523-532.

Pitelis, C. N. 2007. Edith Penrose and a learning-based perspective on the MNE and OLI. Management International Review, 47 (2): 207-220.

Pitelis, C. N., \& Teece, D. J. 2010. Cross-border market cocreation, dynamic capabilities and the entrepreneurial theory of the multinational enterprise. Industrial and Corporate Change, 19(4): 1247-1270.

Polanyi, M. 1958. Personal knowledge. Chicago: University of Chicago Press.

Porter, M. E. 1980. Competitive strategy: Techniques for analyzing industries and competitors. New York: Free Press.

Porter, M. E. 1985. Competitive advantage: Creating and sustaining superior performance. New York: Free Press.

Prahalad, C. K., \& Doz, Y. L. 1981. An approach to strategic control in MNCs. Sloan Management Review, 22(4): 5-13.

Rennie, M. W. 1993. Global competitiveness: Born global. McKinsey Quarterly, 1993(4): 45-52.

Rugman, A. M. 1981. Inside the multinationals: The economics of internal markets. New York: Columbia University Press.

Rugman, A. M., \& Bennett, J. 1982. Technology transfer and world product mandating in Canada. Columbia Journal of World Business, 17(4): 58-62.

Rugman, A. M., \& D'Cruz, I. 2000. Multinationals as flagships firms: Regional business networks. Oxford: Oxford University Press.

Rugman, A. M., \& Verbeke, A. 1992. A note on the transnational solution and the transaction cost theory of multinational strategic management. Journal of International Business Studies, 23(4): 761-771.

Rugman, A. M., \& Verbeke, A. 1993. Foreign subsidiaries and multinational strategic management: An extension and correction of Porter's single diamond framework. Management International Review, 33(Special Issue 2): 71-84.

Rugman, A. M., \& Verbeke, A. 2001. Subsidiary-specific advantages in multinational enterprises. Strategic Management Journal, 22(3): 237-250.

Rugman, A. M., \& Verbeke, A. 2002. Location, competitiveness and the multinational enterprise. In A. M. Rugman, \& T. L. Brewer (Eds), The Oxford handbook of international business: 150-180. Oxford: Oxford University Press.

Rugman, A. M., \& Verbeke, A. 2003. Extending the theory of the multinational enterprise: Internalization and strategic management perspectives. Journal of International Business Studies, 34(2): 125-137.

Rumelt, R. 2011. Good strategy/bad strategy: The difference and why it matters. New York: Crown Business.

Simon, H. A. 1969. The sciences of the artificial. Cambridge, MA: MIT Press.

Starvish, M. 2011. KFC's explosive growth in China. HBS Working Knowledge. http://hbswk.hbs.edu/item/6704.html, accessed 5 August 2012

Szulanski, G. 1996. Exploring internal stickiness: Impediments to the transfer of best practice within the firm. Strategic Management Journal, 17(Winter Special Issue): 27-43.

Tallman, S. 2003. The significance of Bruce Kogut's and Undo Zander's article, "Knowledge of the firm and the evolutionary theory of the multinational enterprise". Journal of International Business Studies, 34(6): 495-497.

Teece, D. J. 1975. The multinational corporation and the resource cost of international technology transfer. Philadelphia: Economics Department, University of Pennsylvania.

Teece, D. J. 1976. The multinational corporation and the resource cost of international technology transfer. Cambridge, MA: Ballinger Publishing.

Teece, D. J. 1977a. Technology transfer by multinational firms: The resource cost of transferring technological know-how. The Economic Journal, 87(346): 242-261.

Teece, D. J. 1977b. Time-cost tradeoffs: Elasticity estimates and determinants for international technology transfer projects. Management Science, 23(8): 830-837.

Teece, D. J. 1980. Economies of scope and the scope of the enterprise. Journal of Economic Behavior and Organization, 1(3): 223-247.

Teece, D. J. 1981a. The multinational enterprise: Market failure and market power considerations. Sloan Management Review, 22(3): 3-17. 
Teece, D. J. 1981b. The market for know-how and the efficient international transfer of technology. Annals of the Academy of Political and Social Science, 458(1): 81-96.

Teece, D. J. 1982. Towards an economic theory of the multiproduct firm. Journal of Economic Behavior and Organization, 3(1): 39-63

Teece, D. J. 1985. Multinational enterprise, internal governance, and industrial organization. American Economic Review, 75(2): 233-238.

Teece, D. J. 1986a. Transaction cost economics and the multinational enterprise: An assessment. Journal of Economic Behavior and Organization, 7(1): 21-45.

Teece, D. J. 1986b. Profiting from technological innovation: Implications for integration, collaboration, licensing and public policy. Research Policy, 15(6): 285-305.

Teece, D. J. 2000. Managing intellectual capital: Organizational, strategic, and policy dimensions. Oxford: Oxford University Press.

Teece, D. J. 2006a. Reflections on the Hymer thesis and the multinational enterprise. International Business Review, 15(2): 124-139.

Teece, D. J. 2006b. Reflections on "Profiting from innovation". Research Policy, 35(8): 1131-1146.

Teece, D. J. 2007. Explicating dynamic capabilities: The nature and microfoundations of (sustainable) enterprise performance. Strategic Management Journal, 28(13): 1319-1350.

Teece, D. J. 2009. Dynamic capabilities and strategic management: Organizing for innovation and growth. New York: Oxford University Press.

Teece, D. J. 2012. Next-generation competition: New concepts for understanding how innovation shapes competition and policy in the digital economy. Journal of Law, Economics, and Policy, 9(1): 97-118.

Teece, D. J. forthcoming. Ordinary capabilities, dynamic capabilities, and competitive advantage: Synthesizing capabilities and the concept of strategy. Academy of Management Perspectives.

Teece, D. J., Pisano, G., \& Shuen, A. 1997. Dynamic capabilities and strategic management. Strategic Management Journal, 18(7): 537-533.

Vahlne, J. -E., \& Johanson, J. 2013. The Uppsala model on evolution of the multinational business enterprise - From internalization to coordination of networks. International Marketing Review, 30(3): 189-210.

Van Mieghem, J. A. 2008. Operations strategy: Principles and practices. Belmont, MA: Dynamic Ideas.

Walker, P. 2009. The (non)theory of the knowledge firm. Scottish Journal of Political Economy, 57(1): 1-32.

Wernerfelt, B. 1984. A resource-based view of the firm. Strategic Management Journal, 5(2): 171-180.
Williamson, O. E. 1975. Markets and hierarchies: Analysis and antitrust implications. New York: Free Press.

Williamson, O. E. 1981. The modern corporation: Origins, evolution, attributes. Journal of Economic Literature, 19(4): 1537-1568.

Williamson, O. E. 1985. The economic institutions of capitalism: Firms, markets, relational contracting. New York: Free Press.

Williamson, O. E. 1991. Comparative economic organization: The analysis of discrete structural alternatives. Administrative Science Quarterly, 36(2): 269-296.

Williamson, O. E. 1999. Strategy research: Governance and competence perspectives. Strategic Management Journal, 20(12): 1087-1108.

Wilson, K., \& Doz, Y. 2011. Agile innovation: a footprint balancing distance and immersion. California Management Review, 53(2): 6-26.

Winter, S. G. 2003. Understanding dynamic capabilities. Strategic Management Journal, 24(10): 991-995.

Zaheer, S. 1995. Overcoming the liability of foreignness. Academy of Management Journal, 38(2): 341-363.

Zahra, S. A., Ireland, R. D., \& Hitt, M. A. 2000. International expansion by new venture firms: International diversity, mode of market entry, technological learning, and performance. Academy of Management Journal, 43(5): 925-950.

\section{ABOUT THE AUTHOR}

David J Teece is the Tusher Chair in Global Business and the Director of the Institute for Business Innovation, Haas School of Business, University of California, Berkeley. He is also chairman of the Berkeley Research Group, and has published over 20 books and over 200 articles on the role of innovation, technical change, and capabilities in the competitive performance of the business enterprise, and on domestic and international policy.

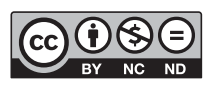

This work is licensed under a Creative Commons Attribution-NonCommercial-NoDerivs 3.0 Unported License. To view a copy of this license, visit http://creativecommons.org/ licenses/by-nc-nd/3.0/ 